\title{
Maleic anhydride-modified chicken ovalbumin as an effective and inexpensive anti-HIV microbicide candidate for prevention of HIV sexual transmission
}

\author{
Lin Li1,2, Pengyuan Qiao², Jie Yang1', Lu Lu², Suiyi Tan¹, Hong Lu², Xiujuan Zhang², Xi Chen², Shuguang Wu', \\ Shibo Jiang ${ }^{* 1,2}$ and Shuwen Liu*1
}

\begin{abstract}
Background: Previous studies have shown that 3-hydroxyphthalic anhydride (HP)-modified bovine milk protein, $\beta$ lactoglobulin ( $\beta-L G)$, is a promising microbicide candidate. However, concerns regarding the potential risk of prion contamination in bovine products and carcinogenic potential of phthalate derivatives were raised. Here we sought to replace bovine protein with an animal protein of non-bovine origin and substitute HP with another anhydride for the development of anti-HIV microbicide for preventing HIV sexual transmission.

Results: Maleic anhydride (ML), succinic anhydride (SU) and HP at different conditions and variable pH values were used for modification of proteins. All the anhydrate-modified globulin-like proteins showed potent anti-HIV activity, which is correlated with the percentage of modified lysine and arginine residues in the modified protein. We selected maleic anhydride-modified ovalbumin (ML-OVA) for further study because OVA is easier to obtain than $\beta-L G$, and $M L$ is safer than HP. Furthermore, ML-OVA exhibited broad antiviral activities against HIV-1, HIV-2, SHIV and SIV. This modified protein has no or low in vitro cytotoxicity to human T cells and vaginal epithelial cells. It is resistant to trypsin hydrolysis, possibly because the lysine and arginine residues in OVA are modified by ML. Mechanism studies suggest that ML-OVA inhibits HIV-1 entry by targeting gp120 on HIV-1 virions and also the CD4 receptor on the host cells.
\end{abstract}

Conclusion: ML-OVA is a potent HIV fusion/entry inhibitor with the potential to be developed as an effective, safe and inexpensive anti-HIV microbicide.

\section{Background}

Despite extraordinary advances in the development of prevention and therapeutic strategies against human immunodeficiency virus (HIV) infection, HIV/AIDS continues to spread at an alarming rate worldwide. There are approximately 7,400 new infections and over 5,500 new deaths resulting from AIDS each day [1,2]. Unprotected sex is the primary infection route for humans, especially for females, to acquire HIV/AIDS. Therefore, the devel-

\footnotetext{
* Correspondence: sjiang@nybloodcenter.org, liusw@smu.edu.cn

1 School of Pharmaceutical Sciences, Southern Medical University, 1838 Guangzhou Avenue North, Guangzhou, Guangdong 510515, China

2 Lindsley F. Kimball Research Institute, New York Blood Center, 310 East 67th Street, New York, NY 10065, USA

Full list of author information is available at the end of the article
}

opment of female-controlled topical microbicides is urgently needed [3-5].

An ideal microbicide should be effective, safe, affordable, and easy to use. We previously found that anhydrate-modified bovine proteins, especially 3hydroxyphthalic anhydride-modified bovine $\beta$-lactoglobulin (3HP- $\beta$-LG), may fulfill these requirements because they have potent antiviral activities against HIV-1, HIV-2, simian immunodeficiency viruses (SIV) and herpes simplex viruses (HSV). 3HP- $\beta$-LG is also effective against some sexually transmitted infection (STI) pathogens, e.g., Chlamydia trachomatis. Furthermore, bovine-based proteins are inexpensive, highly stable in aqueous solution, and easy to formulate into topical gel [6-13]. However, since the epidemic of bovine spongiform encephalopathy 
(BSE) in Europe, serious safety concerns regarding the potential risk of contamination of prion, the pathogen causing BSE, in bovine protein products have been raised. Consequently, the development of bovine protein-based microbicides was discontinued.

Therefore, in the present study, we sought to replace bovine proteins with chemically modified animal proteins of non-bovine origin as new anti-HIV microbicide candidates. All of the non-bovine animal proteins were modified by 3-hydroxyphthalic anhydride (HP), using the same method and the same conditions as 3HP- $\beta$-LG. By evaluating the anti-HIV activities of these modifications and the characteristics of proteins used in the reaction, we found that HP-modified chicken ovalbumin (HPOVA) was the most promising anti-HIV inhibitor among these modified proteins [14]. Since chicken ovalbumin (OVA) is one of the most abundant proteins consumed by people worldwide and is a generally recognized as a safe (GRAS) protein, HP-modified OVA has great potential for further development as an effective, safe and affordable microbicide.

Nonetheless, the phthalate derivatives were reported to have carcinogenic potential $[15,16]$. Therefore, since HPOVA may induce a safety concern when used as a microbicide for the prevention of HIV-1 sexual transmission, we searched for new anhydrides to replace HP. To accomplish this, we compared the efficiency of three different anhydrides, including maleic anhydride (ML), succinic anhydride (SU), as well as HP, for the chemical modification of OVA. The relationship of antiviral activities with the percentage of unmodified lysine and arginine in OVA was also investigated. While not as potent as HP-OVA in blocking HIV-1 infection, the safety profiles indicated that ML-OVA may be a more acceptable anti-HIV microbicide candidate. Further mechanism studies showed that ML-OVA could bind both CD4 and gp120 and block HIV-1 envelope glycoprotein (Env) from binding to CD4, indicating that ML-OVA is an effective HIV entry inhibitor. Furthermore, unlike some potent HIV entry inhibitors which are sensitive to trypsin, such as T20 and C34, this modified ovalbumin is resistant to the hydrolysis of trypsin, suggesting that it would also be a stable microbicide when administered to the human vagina.

\section{Methods}

\section{Reagents}

Maleic anhydride (ML), succinic anhydride (SU), 3hydroxyphthalic anhydride (HP), chicken ovalbumin (OVA, lyophilized powder), rabbit serum albumin (RSA), porcine serum albumin (PSA), bovine serum albumin (BSA), gelatin from cold water fish skin (G-FS), gelatin from porcine skin (G-PS), rabbit anti-OVA serum, FITCgoat-anti-rabbit-IgG, trypsin-agarose beads, phytohemagglutinin (PHA), interleukin-2 (IL-2), XTT [2,3-bis (2- methoxy-4-nitro-5-sulfophenyl)-5-(phenylamino) carbonyl-2H-tetrazolium hydroxide], MTT [3-(4,5-Dimethylthiazol-2-yl)-2,5-diphenyltetrazolium bromide] and 2,4,6-trinitrobenzenesulfonic acid (TNBS) were purchased from Sigma (St. Louis, MO). Calcein-AM was purchased from Molecular Probes Inc. (Eugene, OR). $p$ hydroxyphenylglyoxal ( $p$-HPG) was purchased from Fisher Scientific Co. (Valley Park, VA). Recombinant soluble CD4 (sCD4), biotinylated sCD4, gp120 from HIV$1_{\text {IIIB }}, \mathrm{HIV}-1_{\mathrm{MN}}$, and gp105 from HIV-2 $2_{\text {ROD }}$ were obtained from Immunodiagnostics Inc. (Woburn, MA). Mouse mAb NC-1 specific for the gp41 six-helix bundle was prepared and characterized as previously described [17]. Seminal fluid (SF) was purchased from Lee. BioSolutions. Inc. (St. Louis, Missouri, MO). Vaginal fluid stimulant (VFS) was prepared as described by Owen and Katz [18].

MT-2 cells, CHO-EE cells, CHO-WT cells, TZM-bl cells, HeLa cells, HeLa-CD4-LTR- $\beta$-gal cells, HIV- $1_{\text {IIIB- }}$ infected H9 cells (H9/HIV-1 ${ }_{\text {IIIB }}$ ), U87.CD4.CXCR4 cells, HIV and SIV strains, anti-p24 monoclonal antibody (18312H-5C), HIV immunoglobulin (HIVIG), pNL4-3 plasmid, pVSV-G plasmid, AZT, AMD3100, Maraviroc, T20, and gp120 from $\mathrm{HIV}-1_{\mathrm{BaL}}$ were obtained from the National Institutes of Health AIDS Research and Reference Reagent Program. Lymphoid cell line CEMX174 5.25M7 expressing CD4 and both coreceptors, CCR5 and CXCR4 [19], kindly provided by Dr. C. Cheng-Mayer, were stably transduced with an HIV-1 long terminal repeat (LTR)-green fluorescent protein (GFP) reporter and LTR-luciferase reporter construct cassette. HSV-2 strain 333 (a low-fusion standard laboratory strain) and Vero cells were generous gifts from Guangzhou Institute of Biomedicine and Health of Chinese Academy of Sciences. VK2/E6E7 cells were purchased from American Type Culture Collection (ATCC) (Manassas, VA). C34 and T20 were synthesized by a standard solid-phase Fmoc (9-fluorenylmethoxy carbonyl) method in the MicroChemistry Laboratory of the New York Blood Center and were purified by HPLC.

\section{Chemical modification of proteins with different anhydrides under variable conditions}

The modified proteins were prepared using a previously described method $[6,7,14]$. Briefly, non-bovine-origin proteins (RSA, PSA, OVA, G-FS, and G-PS) were dissolved in $0.1 \mathrm{M}$ phosphate (final concentration, $20 \mathrm{mg} /$ $\mathrm{ml})$. 3-hydroxyphthalic anhydride (HP) (final concentration, $40 \mathrm{mM}$ in dimethylformamide) was added in five aliquots in $12 \mathrm{~min}$ intervals, while $\mathrm{pH}$ was maintained at 8.5. To optimize the conditions for preparation, OVA was treated with 2.5, 5, 10, 20, 40 and $60 \mathrm{mM}$ anhydrides (SU, $\mathrm{ML}$ and $\mathrm{HP}$ ), respectively, or by fixing the concentration of anhydrides in $40 \mathrm{mM}$ and changing the $\mathrm{pH}$ values of the reaction system from 3.0 to 10.0 . The mixtures were 
kept for another $1 \mathrm{~h}$ at room temperature (RT), then extensively dialyzed against phosphate buffer saline (PBS) and filtered through $0.45 \mu \mathrm{m}$ syringe filters (Acrodisc; Gelman Sciences, Ann Arbor, MI).

Protein concentrations were determined using the BCA Protein Assay Reagent Kit (Pierce, Rockford, IL). To determine the molecular weights of the modified proteins or macromolecules, SDS-PAGE was used under denaturing conditions. Standard curve, with the log of molecular weight on the $\mathrm{Y}$ axis and the relative mobility $\left(\mathrm{R}_{\mathrm{f}}\right)$ on the $\mathrm{X}$ axis of each standard protein, was plotted. Based on the linear relationship and the $\mathrm{R}_{\mathrm{f}}$ of modified and unmodified proteins, the molecular weights of those modified proteins or macromolecules were calculated.

To quantify lysine residues in modified or unmodified proteins, a TNBS assay was used as previously described $[14,20]$. Briefly, $25 \mu \mathrm{l}$ of anhydride modified or unmodified proteins $(90 \mu \mathrm{M})$ was treated with $25 \mu \mathrm{Na}_{2} \mathrm{~B}_{4} \mathrm{O}_{7}(0.1$ $\mathrm{M})$ for $5 \mathrm{~min}$ at RT. Then $10 \mu \mathrm{l}$ TNBS were added in the mixture. After another $5 \mathrm{~min}, 100 \mu \mathrm{l}$ stop solution $(0.1 \mathrm{M}$ $\mathrm{NaH}_{2} \mathrm{PO}_{4}$ and $1.5 \mathrm{mM} \mathrm{Na}_{2} \mathrm{SO}_{3}$ ) were added to terminate the reaction. The absorbance at $420 \mathrm{~nm}\left(A_{420}\right)$ was measured using a microplate reader (Ultra 384; Tecan, Research Triangle Park, NC). The percentage of arginine residues modification was also detected using a previously described method [14,21,22]. In brief, $90 \mu \mathrm{l}$ of anhydride modified or unmodified proteins $(90 \mu \mathrm{M})$ in $0.1 \mathrm{M}$ sodium phosphate $(\mathrm{pH}$ 9.0) were treated with $10 \mu \mathrm{l} 50$ $\mathrm{mM} \rho$-HPG for $90 \mathrm{~min}$ at RT in the dark. The absorbance at $340 \mathrm{~nm}\left(A_{340}\right)$ was measured.

\section{Detection of inhibitory activity of anhydride-modified OVA on HIV-1 Env-mediated cell-cell fusion}

The effect of the three modified OVA proteins on HIV-1 Env-mediated viral fusion/entry was determined using two cell-cell fusion assays [23-25]. In the infectious cellcell fusion assay, MT-2 cells expressing CD4 and CXCR4 and the infectious $\mathrm{H} 9 / \mathrm{HIV}-1_{\text {IIIB }}$ cells were used as target and effector cells, respectively. Briefly, $1 \times 10^{4}$ CalceinAM labeled H9/HIV-1 $1_{\text {IIIB }}$ cells were co-cultured with $1 \times$ $10^{5}$ MT-2 cells in the presence or absence of modified OVA at graded concentrations at $37^{\circ} \mathrm{C}$ for $2 \mathrm{~h}$, the fused and unfused Calcein-labeled cells were counted under an inverted fluorescence microscope (Zeiss, Germany). In the non-infectious cell-cell fusion assay, MT-2 cells and the $\mathrm{CHO}-\mathrm{WT}$ cells that are engineered to express HIV-1 Env as target and effector cells, were used respectively. In brief, $1 \times 10^{5} \mathrm{CHO}-\mathrm{WT}$ cells were incubated with $1 \times 10^{5}$ MT-2 cells in the presence or absence of modified OVA at $37^{\circ} \mathrm{C}$ for $48 \mathrm{~h}$. Syncytia were counted under an inverted microscope. The percent inhibition of cell fusion and the $\mathrm{IC}_{50}$ values were calculated using the Calcusyn software [26].

\section{Cytotoxicity assay}

The in vitro cytotoxicity of three anhydride-modified and non-modified OVA to virus target cells (MT-2 and PBMCs) and human vaginal epithelial cells (VK2/E6E7) was measured by the XTT assay. Briefly, $100 \mu \mathrm{l}$ of modified and non-modified proteins at graded concentrations were added to equal volumes of cells $\left(5 \times 10^{5} / \mathrm{ml}\right)$ in wells of 96-well plates. After incubation at $37^{\circ} \mathrm{C}$ for 4 days, 50 $\mu \mathrm{l}$ of XTT solution $(1 \mathrm{mg} / \mathrm{ml})$ containing $0.02 \mu \mathrm{M}$ of phenazine methosulphate (PMS) were added. After $4 \mathrm{~h}$, the absorbance at $450 \mathrm{~nm}\left(A_{450}\right)$ was measured with an ELISA reader. The $50 \%$ cytotoxicity concentrations $\left(\mathrm{CC}_{50}\right)$ were calculated using the CalcuSyn software [27].

\section{Measurement of ML-OVA-mediated antiviral activity}

The inhibitory activity of ML-OVA on infection by laboratory-adapted HIV-1 (IIIB, MN and RF) and AZT-resistant strains was determined as previously described [23,28]. In brief, $1 \times 10^{4} \mathrm{MT}-2$ cells were infected with HIV- 1 at $100 \mathrm{TCID}_{50}$ (50\% tissue culture infective dose) in the presence or absence of ML-OVA at graded concentrations at $37^{\circ} \mathrm{C}$ overnight. Then the culture supernatants were changed with fresh medium. On the fourth day post-infection, $100 \mu \mathrm{l}$ of culture supernatants were collected and mixed with equal volumes of $5 \%$ Triton X-100. Then those virus lysates were assayed for $\mathrm{p} 24$ antigen by ELISA [23]. Briefly, wells of 96-well polystyrene plates (Immulon 1B, Dynex Technology, Chantilly, VA) were coated with $5 \mu \mathrm{g} / \mathrm{ml} \mathrm{HIVIG}$ in $0.85 \mathrm{M}$ carbonate-bicarbonate buffer $(\mathrm{pH} 9.6)$ at $4^{\circ} \mathrm{C}$ overnight, followed by washing with PBS-T buffer (0.01 M PBS containing $0.05 \%$ Tween-20) and blocking with PBS containing $1 \%$ dry fatfree milk (Bio-Rad Inc., Hercules, CA). Virus lysates were added to the wells and incubated at $37^{\circ} \mathrm{C}$ for $1 \mathrm{~h}$. After extensive washes, anti-p24 mAb (183-12H-5C), biotinlabeled anti-mouse IgG (Santa Cruz Biotech., Santa Cruz, CA), streptavidin-labeled horseradish peroxidase (SAHRP) (Zymed, South San Francisco, CA), and 3,3',5,5'tetramethylbenzidine (TMB) (Sigma) were added sequentially. Reactions were terminated by addition of $1 \mathrm{~N}$ $\mathrm{H}_{2} \mathrm{SO}_{4}$. Absorbance at $450 \mathrm{~nm}\left(A_{450}\right)$ was recorded in a microplate reader (Tecan).

To detect the antiviral activities against T20-resistant strains, HIV-2 $2_{\text {ROD }}$, SHIV $_{\text {SF } 33 \mathrm{~A}}$, SHIV $_{\text {SF162P3 }}$ and SIV $_{\mathrm{mac}^{2}} 251$ $32 \mathrm{H}$ viruses, $100 \mathrm{TCID}_{50}$ viruses were incubated with ML-OVA at graded concentrations at $37^{\circ} \mathrm{C}$ for $30 \mathrm{~min}$ prior to the addition to TZM-bl cells. The culture supernatants were changed with fresh medium $24 \mathrm{~h}$ post-infection. At $72 \mathrm{~h}$, the cells were washed and lysed by lysing buffer. Aliquots of cell lysates were transferred to 96-well flat bottom luminometer plates, followed by the addition of luciferase substrate. The luciferase activity was measured in an Ultra 384 luminometer. 
The inhibitory activity of ML-OVA on infection by $\mathrm{HIV}-1_{\mathrm{BaL}}$ and primary HIV-1 isolates was determined as previously described [23]. Peripheral blood mononuclear cells (PBMCs) were isolated from the blood of healthy donors at the New York Blood Center by standard density gradient centrifugation by using Histopaque-1077 (Sigma). The cells were plated in $75-\mathrm{cm}^{2}$ plastic flasks and incubated at $37^{\circ} \mathrm{C}$ for $2 \mathrm{~h}$. The nonadherent cells were collected and resuspended at $5 \times 10^{6} / \mathrm{ml}$ in RPMI 1640 medium containing $10 \% \mathrm{FBS}, 5 \mu \mathrm{g} / \mathrm{ml}$ of phytohemagglutinin (PHA), and $100 \mathrm{U} / \mathrm{ml}$ of interleukin-2, followed by incubation at $37^{\circ} \mathrm{C}$ for 3 days. The PHA-stimulated cells $\left(5 \times 10^{5} / \mathrm{ml}\right)$ were infected with the corresponding primary HIV-1 isolates at $100 \mathrm{TCID}_{50}$ in the absence or presence of ML-OVA at graded concentrations. Culture media were changed every 3 days. The supernatants were collected 7 days post-infection and tested for p24 antigen by ELISA as described above.

A single-round HIV-1 infection assay was performed using $\mathrm{HIV}-1_{\mathrm{NL4}-3}$ virions and TZM-bl cells as previously described [5]. Briefly, $1 \times 10^{4} \mathrm{TZM}$-bl cells were seeded in a 96-well plate and challenged with $\mathrm{HIV}-1_{\mathrm{NL} 4-3}(20 \mathrm{ng} /$ well of p24), which were pre-incubated with a chemically modified or non-modified OVA at graded concentrations for $1 \mathrm{~h}$ at $37^{\circ} \mathrm{C}$. The culture supernatants were replaced with fresh medium $24 \mathrm{~h}$ post-infection. The cells were collected $72 \mathrm{~h}$ post-infection and the luciferase activity was detected as described above.

To determine the antiviral activity of ML-OVA against herpes simplex virus-2 (HSV-2) infection, HSV-2 at 100 $\mathrm{TCID}_{50}$ were incubated with ML-OVA at graded concentrations at $37^{\circ} \mathrm{C}$ for $30 \mathrm{~min}$ prior to the addition to $1 \times 10^{4}$ Vero cells. After culture at $37^{\circ} \mathrm{C}$ for $72 \mathrm{~h}$, virus-induced cytopathic effect (CPE) was detected by MTT assay. Briefly, $10 \mu \mathrm{l}$ of MTT solution $(5 \mathrm{mg} / \mathrm{ml})$ was added to each well, followed by incubation at $37^{\circ} \mathrm{C}$ for $4 \mathrm{~h}$. After the supernatants were removed, $100 \mu \mathrm{l}$ of DMSO was added, and $5 \mathrm{~min}$ later, the absorbance at $570 \mathrm{~nm}$ was measured with an ELISA reader (Tecan GeniousPro).

The effective concentration for $50 \%$ inhibition $\left(\mathrm{IC}_{50}\right)$ was calculated using the Calcusyn software [26], kindly provided by T. C. Chou (Sloan-Kettering Cancer Center, New York, NY).

\section{Time-of-addition assay}

A time-of-addition assay was performed as previously described [14] to determine the in vitro antiviral activity of ML-OVA when added at various time points after virus infection. Briefly, HIV-1 $1_{\text {IIIB }}$ (X4 virus) at 100 TCID $_{50}$ was incubated with $1 \times 10^{5} / \mathrm{ml} \mathrm{MT-2}$ cells for $0,0.5,1,2,4,6$ and $8 \mathrm{~h}$ at $37^{\circ} \mathrm{C}$ before the addition of ML-OVA $(1 \mu \mathrm{M})$, AZT $(0.1 \mu \mathrm{M}), \operatorname{AMD} 3100(0.2 \mu \mathrm{M})$ and T20 $(0.5 \mu \mathrm{M})$, respectively. The culture supernatants were replaced with fresh medium $24 \mathrm{~h}$ post-infection. On the fourth day post-infection, the culture supernatants were collected for measuring p24 antigen as described above. The similar procedure was used for testing the inhibitory activity of ML-OVA against HIV-1 $1_{\mathrm{BaL}}$ (R5), except that $5 \times 10^{5} / \mathrm{ml}$ PHA/IL-2-stimulated PBMCs were used, p24 antigen was tested 7 days post-infection, and AMD3100 was replaced by Maraviroc $(0.1 \mu \mathrm{M})$ as control.

\section{Assessment of inhibition of ML-OVA on HIV-1 transmission from PBMCs to CEMx174 5.25M7 cells}

PHA/IL-2-stimulated PBMCs were isolated and infected by HIV-1 $1_{\text {Bal }}$ (a multiplicity of infection of 0.01 ) for 7 days as described above. After three washes with culture medium to remove free viral particles, $50 \mu \mathrm{l}$ of HIV-1infected PBMCs $\left(1 \times 10^{5} / \mathrm{ml}\right)$ were incubated with $50 \mu \mathrm{l}$ of ML-OVA at graded concentration at $37^{\circ} \mathrm{C}$ for $30 \mathrm{~min}$. Then, $100 \mu \mathrm{l}$ of CEMx174 5.25M7 cells $\left(2 \times 10^{5} / \mathrm{ml}\right)$ were added and co-cultured at $37^{\circ} \mathrm{C}$ for 3 days. The cells were collected and lysed for analysis of luciferase activity, using a luciferase assay kit (Promega) as described above.

\section{Trypsin digestion assay}

The sensitivity of ML-OVA to digestion by trypsin was tested as described before [29]. Trypsin beads were added to ML-OVA (or the control compounds, T20 or C34) diluted in PBS (final concentration of trypsin $=1 \mathrm{U} / \mathrm{ml}$, ML-OVA $=1 \mu \mathrm{M}$, T20 and C34 $=10 \mu \mathrm{M})$, followed by incubation at $37^{\circ} \mathrm{C}$ for different intervals of time $(0,10$, $20,30,45,60,90,120,240,480$ and 1,440 min). The supernatants were then collected for detection of the anti-HIV-1 ${ }_{\text {IIIB }}$ activities as described above.

\section{Detection of the effects of seminal fluid (SF) and vaginal fluid simulant (VFS) on anti-HIV-1 activities of ML-OVA}

The effects of human SF or VFS were determined as previously described [30,31]. SF was first centrifuged at $500 \mathrm{~g}$ for $30 \mathrm{~min}$ to remove spermatozoa. ML-OVA (lyophilized powder) was reconstituted to $550 \mu \mathrm{M}$ with SF, or VFS, or PBS (control), respectively, followed by an incubation at $37{ }^{\circ} \mathrm{C}$ for $60 \mathrm{~min}$. To avoid the toxic effect of SF and VFS on the target cells or viruses, the mixtures were diluted with medium 1000 times (ML-OVA $=0.55 \mu \mathrm{M}$ ) for testing anti-HIV-1 $1_{\text {IIIB }}$ activity and 100 times $(\mathrm{ML}-\mathrm{OVA}=5.5$ $\mu \mathrm{M})$ for testing anti-HIV-1 $1_{\mathrm{BaL}}$ activity, respectively, as described above.

\section{ELISA for detecting the binding of sCD4 with HIV-1 Env}

The interaction between SCD4 and the HIV Env proteins was determined as described before [7,14,32]. Briefly, wells of 96-well polystyrene plates were coated with $5 \mu \mathrm{g} /$ $\mathrm{ml} \mathrm{HIV-1} \mathrm{Env} \mathrm{in} \mathrm{0.1} \mathrm{M} \mathrm{Tris} \mathrm{buffer} \mathrm{(} \mathrm{pH} \mathrm{8.8)}$ ) at $4^{\circ} \mathrm{C}$ overnight, followed by washing with TS buffer $(0.14 \mathrm{M} \mathrm{NaCl}$, $0.01 \mathrm{M}$ Tris, $\mathrm{pH}$ 7.0). Then the wells were blocked for $1 \mathrm{~h}$ 
Table 1: Comparison of the anti-HIV-1 activities and the percentages of modified residues of different compounds modified by 3-hydroxyphthalic anhydride.

\begin{tabular}{|c|c|c|c|c|c|c|}
\hline \multirow{3}{*}{$\begin{array}{l}\text { HP-modified } \\
\text { compounds }\end{array}$} & \multirow{2}{*}{$\begin{array}{l}\% \text { modified } \\
\text { residues }\end{array}$} & & \multicolumn{4}{|c|}{ Inhibitory activity $(\mu \mathrm{M})$ on $^{\mathrm{a}}$} \\
\hline & & & \multicolumn{2}{|c|}{ HIV-1 $1_{\text {IIIB }}$} & \multicolumn{2}{|c|}{ HIV-1 BaL } \\
\hline & Lysine & Arginine & $\mathrm{IC}_{50}$ & $\mathrm{IC}_{90}$ & $\mathrm{IC}_{50}$ & $\mathrm{IC}_{90}$ \\
\hline HP-OVA & $99.27 \pm 0.60$ & $94.36 \pm 1.34$ & $0.006 \pm 0.001$ & $0.019 \pm 0.005$ & $0.118 \pm 0.018$ & $0.359 \pm 0.083$ \\
\hline HP-RSA & $99.00 \pm 0.37$ & $92.65 \pm 1.23$ & $0.003 \pm 0.000$ & $0.006 \pm 0.000$ & $0.297 \pm 0.036$ & $0.574 \pm 0.058$ \\
\hline HP-PSA & $98.66 \pm 0.46$ & $94.31 \pm 1.09$ & $0.005 \pm 0.001$ & $0.012 \pm 0.004$ & $0.411 \pm 0.021$ & $0.823 \pm 0.030$ \\
\hline HP-G-FS & $99.63 \pm 0.08$ & $1.28 \pm 2.21$ & $0.503 \pm 0.157$ & $1.268 \pm 0.221$ & $>8.00$ & $>8.00$ \\
\hline HP-G-PS & $99.81 \pm 0.09$ & $10.48 \pm 1.52$ & $1.182 \pm 0.225$ & $3.561 \pm 1.314$ & $>8.00$ & $>8.00$ \\
\hline
\end{tabular}

aEach sample was tested in triplicate, and the experiment was repeated twice.

at room temperature with $1 \mathrm{mg} / \mathrm{ml}$ bovine serum albumin (BSA) and $0.1 \mathrm{mg} / \mathrm{ml}$ gelatin in TS Buffer. Biotinylated sCD4 $(1 \mu \mathrm{g} / \mathrm{ml})$ was pre-incubated with ML-OVA at the indicated concentrations in PBS containing $100 \mu \mathrm{g} / \mathrm{ml}$ BSA for $18 \mathrm{~h}$ at $4^{\circ} \mathrm{C}$. The mixture, SA-HRP, TMB and $1 \mathrm{~N}$ $\mathrm{H}_{2} \mathrm{SO}_{4}$ were added sequentially. The $A_{450}$ was measured by using an ELISA reader, and the $\mathrm{IC}_{50}$ values were calculated as described above.

\section{ELISA for measuring the binding of ML-OVA to monomeric gp120 or sCD4}

The binding effect of ML-OVA on monomeric gp120 or sCD4 was determined as previously described $[7,32]$. Briefly, wells of 96-well plates were coated with $5 \mu \mathrm{g} / \mathrm{ml}$ of gp120 from HIV-1 $1_{\text {IIIB }}$ or sCD4 in $0.1 \mathrm{M}$ Tris buffer $(\mathrm{pH}$ 8.8 ) at $4^{\circ} \mathrm{C}$ overnight, followed by washing with TS buffer. Then the wells were blocked for $1 \mathrm{~h}$ at RT with $1 \mathrm{mg} / \mathrm{ml}$ BSA and $0.1 \mathrm{mg} / \mathrm{ml}$ gelatin in TS buffer. ML-OVA and non-modified OVA at the indicated concentrations in PBS containing $100 \mu \mathrm{g} / \mathrm{ml}$ BSA were added in wells coated with gp120 or sCD4 for $1 \mathrm{~h}$ at RT. Rabbit antiOVA serum, HRP-goat-anti-rabbit IgG (Sigma), TMB and $1 \mathrm{~N} \mathrm{H}_{2} \mathrm{SO}_{4}$ were added sequentially. The $A_{450}$ was measured by using an ELISA reader, and the $\mathrm{IC}_{50}$ values were calculated as described above.

\section{Flow cytometric analysis of the binding of ML-OVA to cells expressing HIV-1 Env or CD4}

The binding of ML-OVA with CHO-WT cells that express the HIV-1 Env or HeLa-CD4-LTR- $\beta$-gal cells that express CD4 (CHO-EE and HeLa cells bearing neither HIV-1 Env nor CD4 as controls) was determined by flow cytometry as previously described [33,34]. In brief, $100 \mu \mathrm{l}$ of cells $\left(1 \times 10^{7} / \mathrm{ml}\right)$ suspended in PBS contianing $10 \%$ goat serum (PBS-GS) were incubated at $4^{\circ} \mathrm{C}$ for $1 \mathrm{~h}$ before addition of $100 \mu \mathrm{l}$ of ML-OVA $(2 \mu \mathrm{M})$ or OVA $(2 \mu \mathrm{M})$. After incubation at $4^{\circ} \mathrm{C}$ for $1 \mathrm{~h}$, cells were washed three times with PBS-GS. Rabbit anti-OVA serum and FITCgoat-anti-rabbit-IgG were added sequentially. After incubation at $4^{\circ} \mathrm{C}$ for $1 \mathrm{~h}$, the cells were washed and resuspended in $500 \mu \mathrm{l}$ of wash buffer, followed by analysis by flow cytometry.

\section{Results}

Anhydride-modified animal proteins of non-bovine origin were potent inhibitors of HIV-1 infection

Previous studies have shown that bovine milk proteins can be converted into potent inhibitors to prevent sexual transmission of HIV-1 by chemical modification with anhydrides [6,7]. Using a similar approach, we modified five animal proteins of non-bovine origin, including RSA, PSA, OVA, G-FS and G-PS, with a selected acid anhydride, 3-hydroxyphthalic anhydride (HP) and tested their antiviral activities against infections by HIV-1 X4 (HIV$1_{\text {IIIB }}$ ) and R5 (HIV-1 $\left.1_{\mathrm{BaL}}\right)$ viruses. As shown in Table 1, about $99 \%$ of the lysine residues and $>93 \%$ of the arginine residues in the globulin-like proteins RSA, PSA and OVA were modified by HP, and all of these modified proteins exhibited highly potent antiviral activity against HIV-1 $\mathrm{X} 4$ virus, but were less effective against HIV-1 R5 virus. In the two gelatins, G-FS and G-PS, almost $100 \%$ of the lysine residues, but only $1-10 \%$ of the arginine residues, were chemically modified. Both HP-G-FS and HP-G-PS could also inhibit HIV-1 $1_{\text {IIIB }}$ infection activity, but were about 100 -fold less potent than HP-modified globulinlike proteins. Neither HP-G-FS nor HP-G-PS could inhibit HIV-1 $1_{\mathrm{Bal}}$ infection at the concentration of $8 \mu \mathrm{M}$.

Although HP-RSA and HP-PSA exhibited anti-HIV-1 activity similar to HP-OVA, we selected HP-OVA for further studies because OVA which is isolated from chicken 
eggs is much less expensive than RSA and PSA which are purified from animal sera.

\section{Optimization of experimental conditions for preparation of the most active anhydride-modified ovalbumin}

To search for alternate anhydrides to replace 3hydroxyphthalic anhydride (HP) for modifying OVA, two other anhydrides, maleic anhydride (ML) and succinic anhydride (SU) were used. To optimize the experimental conditions for production of anhydride-modified ovalbumin, we compared the efficacy of SU, ML and HP at different concentrations $(2.5,5,10,20,40$ and $60 \mathrm{mM})$. With the increasing concentrations of anhydrides used, the percentages of the modified lysine and arginine residues increased, reaching a plateau when $40 \mathrm{mM}$ of the anhydrides were used (Fig. 1A and 1B). Then, the possible effect of $\mathrm{pH}$ value on the modifications of the lysine and arginine residues in OVA was evaluated by using a fixed concentration $(40 \mathrm{mM})$ of anhydrides under variable reaction system $\mathrm{pH}$ values (3.0 10.0). As shown in Fig. $2 \mathrm{~A}$ and $2 \mathrm{~B}$, the percentages of the modified lysine and arginine residues in the modified OVA increased with the increasing $\mathrm{pH}$ value of the reaction system. A plateau was reached when the $\mathrm{pH}$ was over 8.0.

Based on these results, the average $\mathrm{pH}$ of 8.5 and 40 $\mathrm{mM}$ of anhydrite were selected as the optimal parameters in subsequent experiments. Under these optimal experimental conditions, the average molecular weights of MLOVA, SU-OVA and HP-OVA were 45.59, 44.58 and 44.58 $\mathrm{kd}$, respectively, as determined by SDS-PAGE. In addition, $99.19 \%, 88.40 \%$ and $99.86 \%$ of the lysine residues and $92.46 \%, 98.58 \%$ and $89.26 \%$ of the arginine residues were modified by ML, SU and HP, respectively.

Notably, the percentages of the modified lysine and arginine residues appear correlated with the anti-HIV$1_{\text {IIIB }}$ (Fig. 1C and 2C) and anti-HIV-1 $1_{\text {BaL }}$ (Fig. 1D and 2D) activity of these modified OVA. Both ML-OVA and HPOVA with higher percentages of modified lysine and arginine residues had more potent anti-HIV-1 activity than SU-OVA. Similar results were seen in the effectiveness on HIV Env-induced cell-cell fusion (Table 2).

The cytotoxicity of these three modified OVA and unmodified OVA proteins was determined using MT-2, PBMC and VK2/E6E7 cells. As shown in Table 3, the cytotoxicities of ML-OVA and HP-OVA to MT-2, PBMC and VK2/E6E7 cells were about one- and 3-fold higher than that of unmodified OVA, respectively, suggesting that HP-modified proteins exhibit higher cytotoxicity than ML-modified proteins.

Though HP-OVA was found to be the most potent modified OVA, we selected the second most effective one, ML-OVA, for further study because of the concerns over the possibility that HP-modified proteins might generate some phthalate derivatives with carcinogenic potential [35-38]. In addition, HP-OVA displayed higher cytotoxicity than ML-OVA (Table 3 ).

\section{ML-OVA exhibited potent inhibitory activity against infection by HIV-1, HIV-2, SIV, SHIV and HSV-2 strains}

The inhibitory activities of ML-OVA against virus infection were tested on HIV-1, HIV-2, SIV, SHIV and HSV-2 strains. As shown in Table 4, ML-OVA exhibited highly potent inhibitory activity against infection by the laboratory-adapted HIV-1 X4 and X4R5 strains with $\mathrm{IC}_{50}$ at $\mathrm{nM}$ levels, while it inhibited infection by laboratory-adapted and primary HIV-1 R5 strain with $\mathrm{IC}_{50}$ at low $\mu \mathrm{M}$ level. Notably, it was also effective against HIV-1 variants resistant to AZT, a reverse transcriptase inhibitor, and enfuvirtide, an HIV fusion/entry inhibitor, with $\mathrm{IC}_{50}$ at $\mathrm{nM}$ level. Interestingly, ML-OVA could also inhibit infection by HIV-2, SIV, SHIV and HSV-2 strains, although the $\mathrm{IC}_{50}$ values on HIV-2 and HSV-2 were relatively high. These results suggest that ML-OVA displays broad and potent antiviral activities against HIV and SIV.

\section{ML-OVA inhibited transmission of cell-associated HIV-1BaL} virus from PBMCs to CEMx174 5.25M7 cells

To determine whether ML-OVA could inhibit HIV- $1_{\mathrm{BaL}}$ transmission from PBMCs to CEMx174 5.25M7 cells, PBMCs infected by $\mathrm{HIV}-1_{\mathrm{BaL}}$ were cocultured with CEMx174 5.25M7 cells in the presence of ML-OVA at graded concentrations. After 3 days, the level of luciferase activity, representing HIV-1 infectivity in CEMx174 5.25M7 cells, was measured. As shown in Fig. 3, MLOVA blocked transmission of HIV-1 $1_{\mathrm{BaL}}$ from PBMCs to CEMx174 5.25M7 cells, suggesting that it can prevent transmission of cell-associated HIV-1 isolates.

\section{ML-OVA exerted its antiviral action at the early stage of HIV-1 replication}

ML-OVA was shown to inhibit HIV-1 Env-mediated cellcell fusion (Table 2), suggesting that it may inhibit HIV-1 infection by blocking HIV-1 entry. Here we performed a single-round entry assay using HIV-1 $1_{\mathrm{NL4}-3}$ virions and TZM-bl cells. The results showed that ML-OVA, HPOVA, and SU-OVA, all inhibited single-round virus entry, while the unmodified OVA had no such activity (Fig. 4). ML-OVA could not block the single round entry of the VSV-G pseudovirus (data not shown), suggesting that ML-OVA may specifically target HIV-1 at the entry stage. To determine whether ML-OVA could also act at the late stage of the HIV-1 replication, we carried out a time-of-addition assay using both $\mathrm{X} 4$ and R5 HIV-1 strains and the well-know HIV-1 entry/fusion inhibitors and RTI as controls. As shown in Fig. 5, the nucleoside reverse transcriptase inhibitor (NRTI) - AZT exhibited potent anti-HIV-1 activity against both $\mathrm{X} 4$ virus $\mathrm{HIV}-1_{\text {IIIB }}$ 


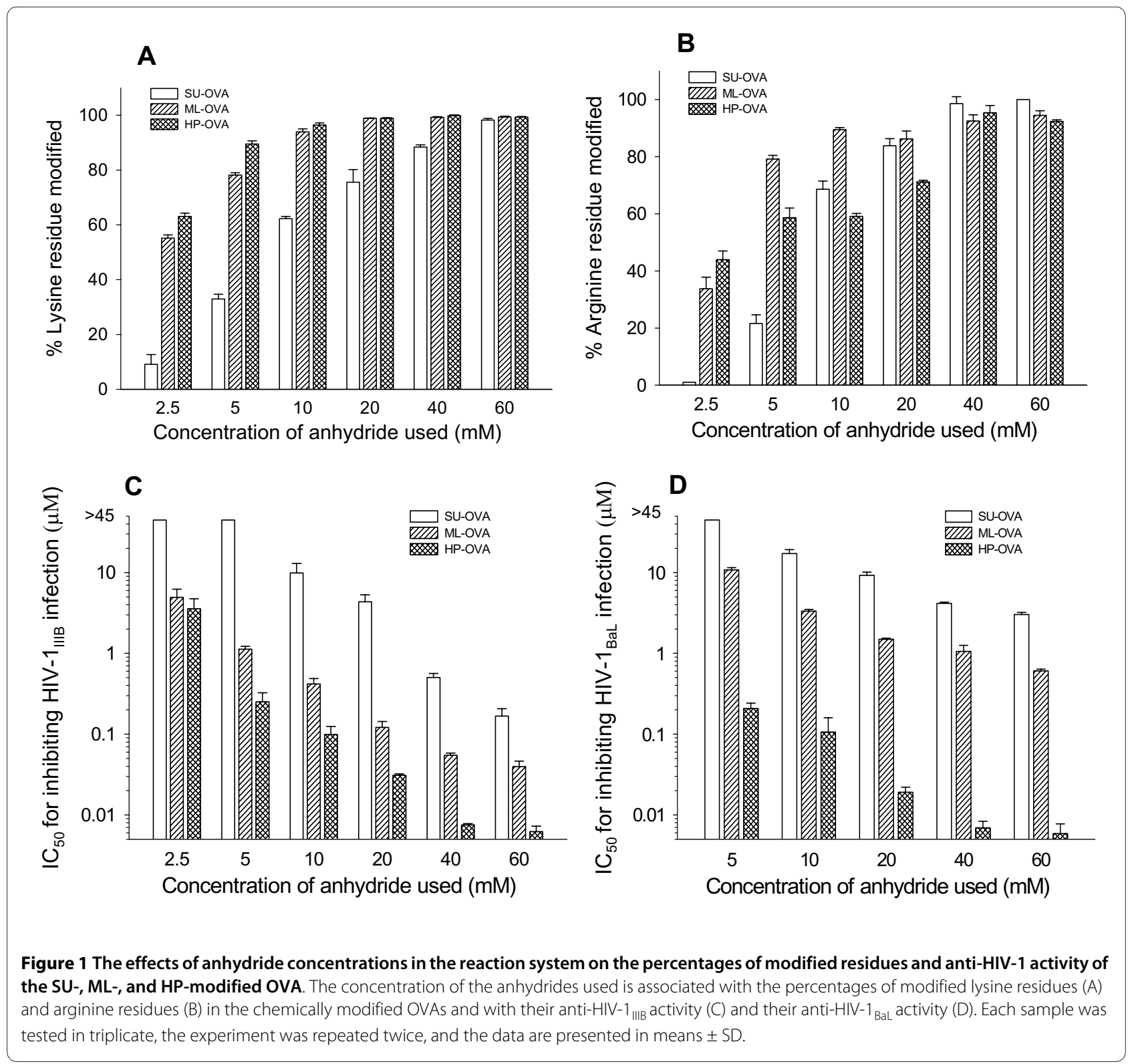

and R5 virus $\mathrm{HIV}-1_{\mathrm{BaL}}$ when it was added to cells before viral infection and $1 \sim 8 \mathrm{~h}$ post-infection, while the HIV entry inhibitors, such as T20 (against both HIV-1 $1_{\text {IIIB }}$ and HIV-1 ${ }_{\text {BaL }}$ ), AMD-3100 (against HIV-1 $1_{\text {IIIB }}$ ) and Maraviroc (against HIV-1 $1_{\mathrm{BaL}}$ ), exhibited significantly decreased inhibitory activity when they were added $0.5 \sim 2 \mathrm{~h}$ postinfection. ML-OVA showed inhibitory profiles similar to those of HIV entry inhibitors, suggesting that ML-OVA exerts its antiviral action at the early stage of HIV-1 replication.

\section{ML-OVA bound with cells express HIV-1 Env or CD4}

As mentioned above, ML-OVA is highly effective in inhibiting fusion between the effector and target cells, suggesting that it may interact with either the HIV-1 Env on the effector cells or the CD4 receptor on the target cells. Here we used flow cytometry to analyze the binding activity of ML-OVA to CHO-WT cells that express HIV1 Env or HeLa-CD4-LTR- $\beta$-gal cells that express CD4 molecule, using CHO-EE and HeLa cells that express neither HIV-1 Env nor CD4 as controls. The results showed that ML-OVA could significantly bind with both CHOWT and HeLa-CD4-LTR- $\beta$-gal cells (Fig. 6A, and 6E). However, it had only background binding to $\mathrm{CHO}-\mathrm{EE}$ and HeLa cells (Fig. 6B and 6F), at the similar level as the unmodified OVA (Fig. 6C, D, G and 6H). These results suggest that ML-OVA is able to interact with both HIV-1 Env and CD4 receptor on cell surfaces. 


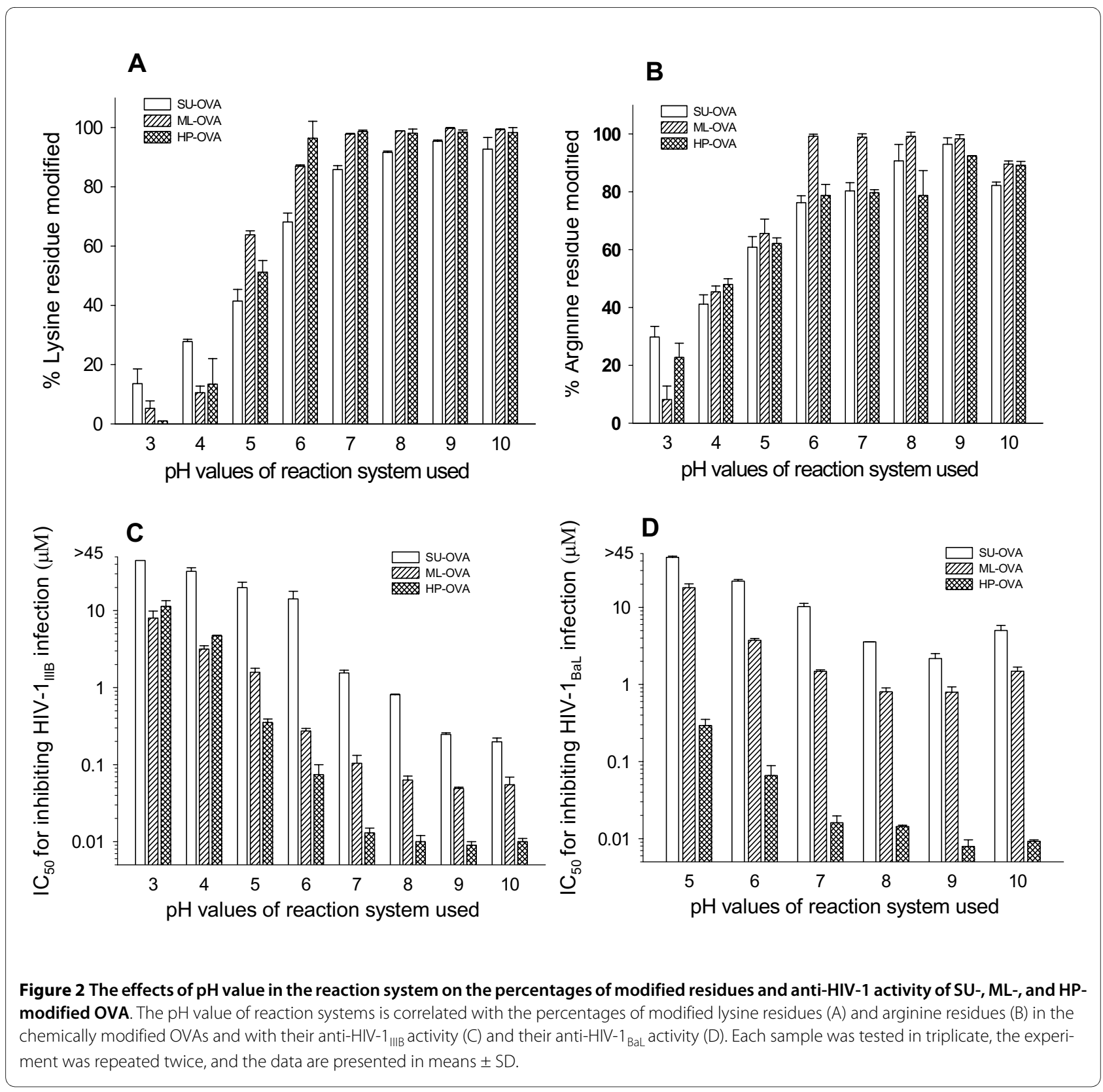

ML-OVA bound with both gp120 and CD4 molecules and blocked the gp120-CD4 interaction

The first step of HIV-1 entry into a $\mathrm{CD} 4^{+}$target cell occurs when the surface subunit gp120 of the HIV-1 Env binds to CD4 [39]. Previous study has shown that 3HP- $\beta$ LG interfered with the binding of CD4 to HIV and SIV surface Envs as well as monoclonal antibodies specific to the gp120 binding site on CD4 [11]. Using similar approaches, we determined the potential effect of MLOVA on the interaction between sCD4 and gp120 or gp105, the surface subunits of HIV-1 or HIV-2 Env, respectively. As shown in Table 5, ML-OVA was highly effective in blocking the interaction between $\mathrm{sCD} 4$ and gp120 from HIV-1 $1_{\mathrm{III}}$, HIV-1 $1_{\mathrm{BaL}}$, and $\mathrm{HIV}-1_{\mathrm{MN}}$ and between $\mathrm{SCD} 4$ and gp105 from HIV-2 ${ }_{\mathrm{ROD}}$, while unmodified OVA exhibited no inhibition at the concentration up to $100 \mu \mathrm{M}$. These results indicate that the inhibition of HIV entry by ML-OVA may be attributed to its inhibitory effect on viral gp120 binding to the CD4 molecule on the target cell.

To further characterize the target of ML-OVA, the interaction of ML-OVA with gp120 or sCD4 was examined by ELISA. The results showed that the interaction of sCD4 (Fig. 7A) and gp120 from HIV-1 $1_{\text {IIIB }}$ (Fig. 7B) bound with ML-OVA in a dose-dependent manner. Unmodified OVA exhibited no significant binding effects at the con- 
Table 2: Inhibitory activity of modified OVA on HIV-1-mediated cell-cell fusiona.

\begin{tabular}{|c|c|c|c|c|c|}
\hline \multirow[t]{2}{*}{ Modified OVAs } & \multirow[t]{2}{*}{ Anhydride } & \multicolumn{2}{|c|}{ Fusion by MT-2 \& CHO-WT } & \multicolumn{2}{|c|}{ Fusion by MT-2 \& H9/HIV-1 ${ }_{\text {IIIB }}$} \\
\hline & & $\mathrm{IC}_{50}(\mu \mathrm{M})$ & $\mathrm{IC}_{90}(\mu \mathrm{M})$ & $\mathrm{IC}_{50}(\mu \mathrm{M})$ & $I C_{90}(\mu \mathrm{M})$ \\
\hline ML-OVA & & $0.193 \pm 0.003$ & $0.789 \pm 0.186$ & $0.411 \pm 0.090$ & $1.021 \pm 0.222$ \\
\hline SU-OVA & & $0.406 \pm 0.047$ & $1.986 \pm 0.091$ & $1.462 \pm 0.142$ & $3.338 \pm 0.326$ \\
\hline HP-OVA & & $0.186 \pm 0.004$ & $0.386 \pm 0.006$ & $0.057 \pm 0.005$ & $0.135 \pm 0.007$ \\
\hline OVA & & $>100$ & $>100$ & $>100$ & $>100$ \\
\hline
\end{tabular}

aThe measurements were performed in triplicate, and the experiment was repeated twice. Data are presented in means \pm SD.

centration up to $1 \mu \mathrm{M}$. From the $\mathrm{OD}_{450}$ values of the binding assays, ML-OVA bound with gp120 more efficiently than with CD4. These results indicate that the targets of ML-OVA are both on gp120 and CD4, especially gp120.

\section{ML-OVA was resistant to trypsin hydrolysis}

Trypsin is one of the principal digestive proteases in the human body, especially in the vaginal flora, which predominantly hydrolyzes proteins/peptides at the carboxyl side of arginine and lysine residues. Since most lysine and arginine residues in OVA had been modified by ML, we intended to know whether ML-OVA is susceptible to trypsin hydrolysis by measuring the anti-HIV-1 $1_{\text {IIIB }}$ activity of ML-OVA treated with trypsin. As shown in Fig. 8, ML-OVA retained more than $80 \%$ of its anti-HIV-1 activity even $24 \mathrm{~h}$ after its incubating with trypsin beads, while the peptidic HIV-1 fusion inhibitors, C34 and T20, lost most of their antiviral activities $2 \mathrm{~h}$ post-treatment with trypsin. These results indicate that ML-modified ovalbumin become resistant to trypsin hydrolysis.

\section{SF and VFS had no significant effect on the anti-HIV-1} activity of ML-OVA

Human body fluids such as seminal and vaginal fluids may have negative effect on the efficacy of the topical microbicides $[30,31,40]$, while sexual transmission of HIV occurs in presence of those human body fluids. Therefore, it is necessary to determine the potential effect of SF and VFS on the anti-HIV activity of ML-OVA. As shown in Fig. 9, neither SF nor VFS had significant effect on the inhibitory activity of ML-OVA against infection by HIV-1 $\mathrm{X} 4$ and $\mathrm{R} 5$ strains. The $\mathrm{IC}_{50}$ values of ML-OVA for inhibiting HIV-1 $1_{\text {IIIB }}$ infection in the presence of SF and VFS were $0.045 \mu \mathrm{M}$ and $0.030 \mu \mathrm{M}$, respectively, while that of PBS control is $0.031 \mu \mathrm{M}$. The $\mathrm{IC}_{50}$ values of ML-OVA for inhibiting $\mathrm{HIV}-1_{\mathrm{BaL}}$ infection in the presence of SF and VFS were $1.029 \mu \mathrm{M}$ and $1.033 \mu \mathrm{M}$, respectively, whereas that of PBS control is $0.769 \mu \mathrm{M}$. Those results suggest that SF and VFS have no negative effect on the application of ML-OVA as a microbicide.

Table 3: In vitro cytotoxicity of anhydrate-modified OVAa.

\begin{tabular}{|c|c|c|c|c|c|c|}
\hline \multirow[t]{2}{*}{ Modified OVAs } & \multicolumn{2}{|c|}{ MT-2 } & \multicolumn{2}{|c|}{ PBMC } & \multicolumn{2}{|c|}{ VK2/E6E7 } \\
\hline & $\mathrm{CC}_{50}(\mu \mathrm{M})$ & $\mathrm{CC}_{90}(\mu \mathrm{M})$ & $C C_{50}(\mu M)$ & $\mathrm{CC}_{90}(\mu \mathrm{M})$ & $C C_{50}(\mu M)$ & $\mathrm{CC}_{90}(\mu \mathrm{M})$ \\
\hline ML-OVA & $187.33 \pm 2.329$ & $465.18 \pm 34.16$ & $148.29 \pm 14.51$ & $447.33 \pm 84.30$ & $140.49 \pm 6.840$ & $501.60 \pm 35.96$ \\
\hline SU-OVA & $270.93 \pm 6.838$ & $540.69 \pm 12.60$ & $161.84 \pm 6.446$ & $927.39 \pm 74.16$ & $188.84 \pm 52.69$ & $480.76 \pm 240.94$ \\
\hline HP-OVA & $99.18 \pm 3.095$ & $256.14 \pm 10.58$ & $90.28 \pm 4.113$ & $414.22 \pm 52.99$ & $78.39 \pm 1.760$ & $331.02 \pm 16.44$ \\
\hline OVA & $340.34 \pm 43.22$ & $938.72 \pm 513.41$ & $357.20 \pm 58.06$ & $896.26 \pm 309.08$ & $253.09 \pm 74.92$ & $904.94 \pm 795.89$ \\
\hline
\end{tabular}

aEach sample was tested in triplicate, and the experiment was repeated twice. 
Table 4: Antiviral activities of ML-OVA against infection by HIV-1, HIV-2, SHIV, SIV and HSV-2 strains.

\begin{tabular}{|c|c|c|}
\hline \multirow[t]{2}{*}{ Virus strain } & \multicolumn{2}{|c|}{ Inhibitory activity (Mean \pm SD, $\mu M)^{a}$} \\
\hline & $I C_{50}$ & $I C_{90}$ \\
\hline \multicolumn{3}{|c|}{ Laboratory-adapted HIV-1 strains } \\
\hline IIIB (X4) & $0.023 \pm 0.004$ & $0.057 \pm 0.004$ \\
\hline MN (X4) & $0.151 \pm 0.008$ & $0.821 \pm 0.103$ \\
\hline RF (X4R5) & $0.034 \pm 0.005$ & $0.147 \pm 0.059$ \\
\hline $\mathrm{BaL}$ (R5) & $0.690 \pm 0.109$ & $2.236 \pm 1.184$ \\
\hline \multicolumn{3}{|l|}{ Primary HIV-1 strains } \\
\hline UG94103(clade A, X4R5) & $0.561 \pm 0.159$ & $2.520 \pm 1.231$ \\
\hline 92US657 (clade B, R5) & $2.107 \pm 0.263$ & $9.357 \pm 1.939$ \\
\hline 93IN101 (clade C, R5) & $1.208 \pm 0.535$ & $4.946 \pm 0.632$ \\
\hline BCF02 (clade O, R5) & $0.067 \pm 0.004$ & $0.188 \pm .0 .010$ \\
\hline Ru570 (clade G, R5) & $4.299 \pm 0.298$ & $9.332 \pm 0.594$ \\
\hline \multicolumn{3}{|l|}{ Drug-resistant HIV-1 } \\
\hline AZT-R b & $0.296 \pm 0.052$ & $1.099 \pm 0.773$ \\
\hline $\mathrm{NL} 4-3_{\mathrm{D} 36 \mathrm{G}}{ }^{\mathrm{C}}$ & $0.104 \pm 0.019$ & $0.591 \pm 0.059$ \\
\hline $\mathrm{NL} 4-3_{(36 \mathrm{G}) \mathrm{V} 38 \mathrm{~A}^{\mathrm{c}}}$ & $0.185 \pm 0.027$ & $0.543 \pm 0.026$ \\
\hline NL4-3 ${ }_{(36 G) V 38 E / N 42 T^{c}}$ & $0.156 \pm 0.082$ & $0.992 \pm 0.438$ \\
\hline \multicolumn{3}{|l|}{ HIV-2 } \\
\hline ROD & $6.079 \pm 1.907$ & $12.59 \pm 3.022$ \\
\hline \multicolumn{3}{|l|}{ SIV } \\
\hline $\operatorname{mac} 25132 \mathrm{H}$ & $0.307 \pm 0.174$ & $6.128 \pm 2.078$ \\
\hline \multicolumn{3}{|l|}{ SHIV } \\
\hline SF33A (X4) & $0.189 \pm 0.103$ & $1.505 \pm 0.872$ \\
\hline SF162P3 (R5) & $1.312 \pm 0.688$ & $11.63 \pm 5.477$ \\
\hline \multicolumn{3}{|l|}{ HSV } \\
\hline HSV-2 strain 333 & $39.06 \pm 2.316$ & $69.49 \pm 3.145$ \\
\hline
\end{tabular}

\section{Discussion}

In the present study, we screened for ideal chemically modified agents as potential microbicides, and five nonbovine-origin proteins were used in our studies. First, these agents were modified by one anhydride, 3hydroxyphthalic anhydride (HP). By evaluating their antiHIV-1 activities against lab-adapted X4 and R5 viruses, it was revealed that some common proteins, such as OVA, RSA and PSA, could be converted into effective anti-HIV inhibitors by modification of their positive residues (lysine and arginine) with 3HP (Table 1). On the other hand, HP-modified proteins from gelatins displayed very low anti-HIV-1 activity with uncharacteristically high percentages of lysine modification. By analyzing the structure of the proteins found to possess antiviral activity, OVA, RSA and PSA were found to have representative globulins identical to bovine $\beta$-lactoglobulin. By contrast, the gelatins used in this study are derived from collagens, which had different structure and conformation. The absence of anti-HIV activities of these modified proteins indicated that HIV blocking abilities might not be solely dependent on the modified lysine or arginine but also on the protein conformation. Thus, the presence of specific globular structures might play an important role in the anti-HIV activity of OVA, RSA and PSA.

Although both RSA and PSA exhibited anti-HIV-1 activity similar to OVA after modification with HP, we selected OVA for further studies. Ovalbumin is the main 


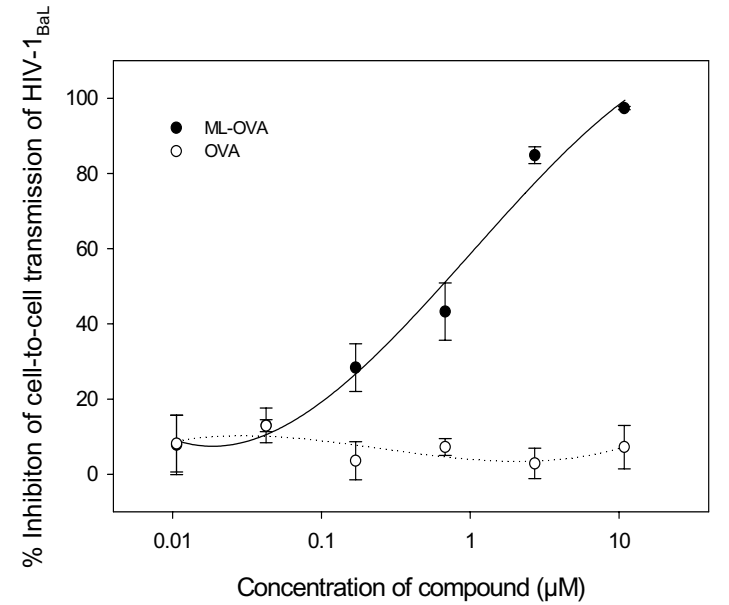

Figure 3 ML-OVA-mediated inhibition of transmission of HIV-1 ${ }_{\mathrm{BaL}}$ from PBMCs to CEMx174 5.25M7 cells. All the samples were tested in triplicate, the experiment was repeated twice, and the data are presented in means \pm SD.

protein found in egg white with a molecular weight of about $43 \mathrm{kd}$ by SDS-PAGE. It is made up of 385 amino acids, containing 20 lysine $(5.19 \%)$ and 15 arginine $(3.90 \%)$ residues [41,42]. Most of these positively charged amino acids in the protein have been modified by anhydrides, which could convert the proteins into anti-HIV inhibitors (Table 1). Importantly, because OVA is easily isolated from chicken eggs, it is much more economical than albumins purified from animal sera. Furthermore, the products from sera have the added risk of contamination by infectious pathogens. Since an ideal microbicide

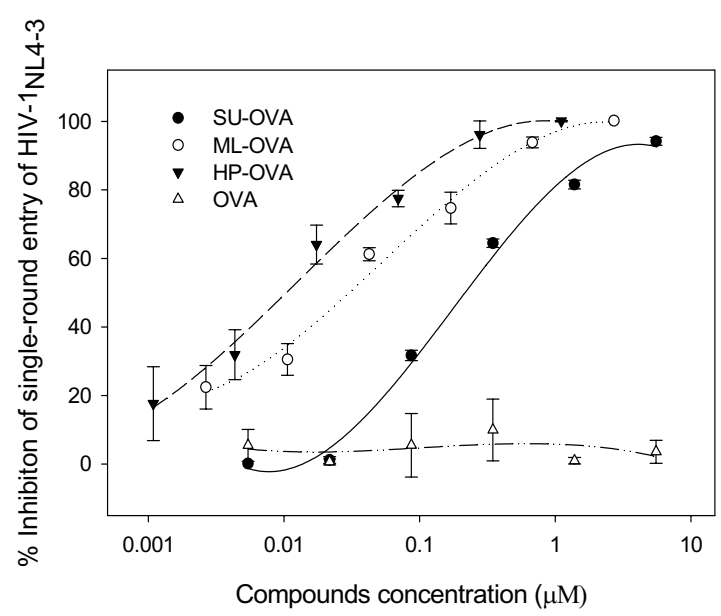

Figure 4 Inhibition of chemically modified OVA on single round entry of $\mathrm{HIV}-\mathbf{1}_{\mathrm{NL} 4-3}$. Each sample was tested in triplicate, the experiment was repeated twice, and the data are presented in means \pm SD. should be inexpensive and safe, chicken OVA may be the most suitable protein for modification as an anti-HIV agent to prevent HIV sexual transmission.

OVA is a common antigen used in the immunogenicity studies. One may raise a concern about the potential of ML-OVA to induce harmful immune responses in vaginal mucosa when it is used as a topical microbicide. However, a number of studies have showed that mucosal immunization through intravaginal and intrarectal administration with soluble proteins, including OVA, in absence of adjuvants, are usually unable to induce strong local immune responses [43-45]. Therefore, intravaginal or intrarectal application of ML-OVA as a microbicide may not be expected to elicit harmful local immune responses. Another problem for the development of chemically modified OVA as a topical microbicide is the potential risk of causing side effect in people who are allergy to egg protein [46]. But fortunately, egg allergy occurs seldomly in adults, but mostly in young children (less than 5 years old) [47]. Therefore, we expect that there will be only very few adults with egg allergy, and those people should be excluded from the clinical trials of ML-OVA-based microbicide.

Although HP-OVA is a potent anti-HIV agent, the phthalate derivatives were reported to have carcinogenic potential [35-38]. Therefore, the use of HP-OVA as a microbicide for the prevention of HIV-1 sexual transmission raises safety questions. To search for alternate anhydrides as chemical modifiers of OVA, we selected two other anhydrides, succinic anhydride (SU) and maleic anhydride (ML), for the chemical modification. $\mathrm{SU}$ is one of the food additives or pharmaceutical excipients. Carcinogenesis studies of SU in B6C3F1 mice and F344/N rats performed by National Toxicology Program showed that SU had no carcinogenic activity [48]. ML is also a common anhydride used in pharmaceuticals. A maleic anhydride-divinyl ether copolymer (MVE-2) was shown to inhibit mammary and urinary bladder carcinogenesis [49].

All three anhydrides (SU, ML and HP) were sufficiently potent to convert OVA into an effective anti-HIV agent. The percentages of modified and unmodified lysine and arginine residues were dependent on the concentration of anhydrides and $\mathrm{pH}$ of the reaction system with the strength of anti-HIV activity correlated to the successive increase of positively charged residues. These results were consistent with our previous studies with 3 HP- $\beta$-LG $[6,7]$. Therefore, the optimal condition to produce potent anti-HIV modified OVAs, as suggested from this study, is $40 \mathrm{mM}$ anhydride used at $\mathrm{pH} 8.5$ for $20 \mathrm{mg} / \mathrm{ml}$ OVA. Under this condition, ML-OVA demonstrated more efficacy than SU-OVA in blocking HIV-1 infection, especially the sexually transmitted R5 virus. Furthermore, a series of poly [styrene-alt-(maleic anhydride)] derivatives 

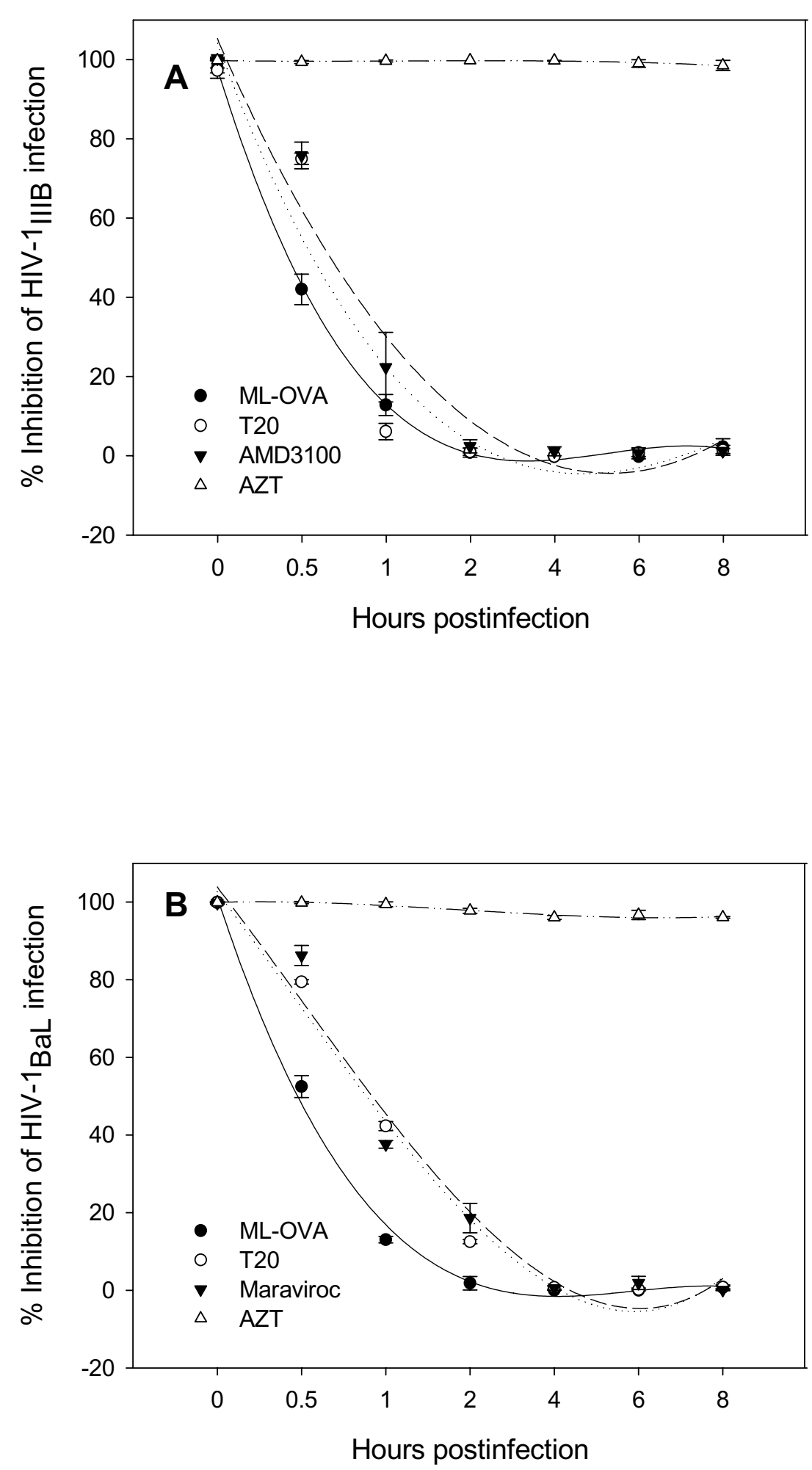

Figure 5 Time-of-addition assay. Inhibition of infection by HIV-1 ${ }_{\text {IIIB }}(A)$ and HIV-1 ${ }_{\text {BaL }}$ (B) by ML-OVA and the control compounds when added at different intervals post-infection was tested using a time-of-addition assay. Each sample was tested in triplicate, the experiment was repeated twice, and the data are presented in means \pm SD. 

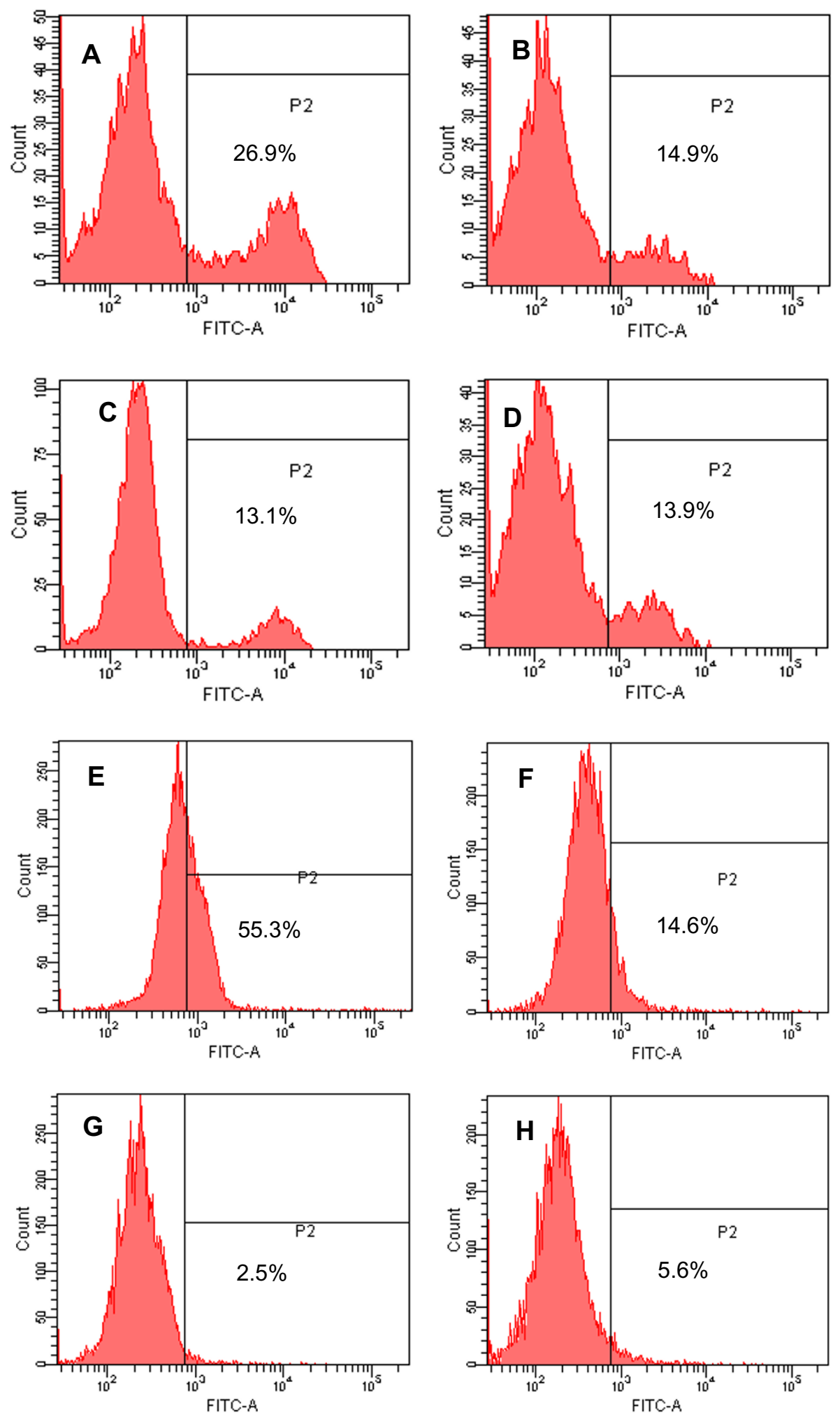

Figure 6 Flow cytometric analysis of binding of ML-OVA to cells expressing HIV-1 Env or CD4 molecule. (A) ML-OVA + CHO-WT cells; (B) MLOVA + CHO-EE cells; (C) OVA + CHO-WT cells; (D) OVA + CHO-EE cells; (E) ML-OVA + HeLa-CD4-LTR- $\beta$-gal cells; (F) ML-OVA + HeLa cells; (G) OVA + HeLa-CD4-LTR- $\beta$-gal cells; and (H) OVA + HeLa cells. 
Table 5: Inhibitory activity of ML-OVA on the association between SCD4 and distinct HIV envelope proteins.

\begin{tabular}{|c|c|c|c|c|c|}
\hline \multirow{2}{*}{$\begin{array}{c}\text { Chemically } \\
\text { modified protein }\end{array}$} & \multirow{2}{*}{$\begin{array}{c}\text { Inhibitory activity } \\
(\mu \mathrm{M})^{\mathrm{a}}\end{array}$} & \multicolumn{4}{|c|}{ The HIV envelope proteins } \\
\hline & & gp120 of HIV-1 $1_{\text {IIIB }}$ & gp120 of HIV-1 ${ }_{M N}$ & gp120 of HIV-1 ${ }_{B a L}$ & gp105 of HIV-2 ${ }_{\text {ROD }}$ \\
\hline \multirow[t]{2}{*}{ ML-OVA } & $\mathrm{IC}_{50}$ & $0.471 \pm 0.063$ & $1.161 \pm 0.092$ & $1.397 \pm 0.008$ & $0.466 \pm 0.076$ \\
\hline & $\mathrm{IC}_{90}$ & $3.258 \pm 0.413$ & $8.567 \pm 2.360$ & $19.77 \pm 1.491$ & $11.36 \pm 3.721$ \\
\hline \multirow[t]{2}{*}{ OVA } & $\mathrm{IC}_{50}$ & $>100$ & $>100$ & $>100$ & $>100$ \\
\hline & $\mathrm{IC}_{90}$ & $>100$ & $>100$ & $>100$ & $>100$ \\
\hline
\end{tabular}

aThe measurements were performed in triplicate, and the experiment was repeated twice. Data are presented in means \pm SD.

were reported as potential microbicide candidates with high efficacy and low cytotoxicity [50]. Therefore, we selected ML-OVA for further investigation.

ML-OVA displayed broad antiviral activities against HIV-1, HIV-2 and SIV with low cytotoxicity. While MLOVA is less potent against laboratory-adapted R5 BaL strain than $\mathrm{X} 4$ strains, it is effective in inhibiting the infection of primary R5 viruses with distinct genotypes and phenotypes (Table 4). Interestingly, ML-OVA was shown to be effective against the HIV-1 variants resistant to AZT and T20 (Table 4), suggesting that ML-OVA is capable of preventing the sexual transmission of HIV-1 strains that are resistant to the currently used antiretroviral therapeutics. In addition, ML-OVA is effective in inhibiting HIV-2 infection, suggesting that this microbicide candidate may also be applicable in West Africa where HIV-2 is prominent. Our studies also showed that ML-OVA could potently inhibit infection by SHIV $_{\text {SF162 }}$ (R5), $\mathrm{SHIV}_{\mathrm{SF33 \textrm {A }}}(\mathrm{X} 4)$ and SIV with $\mathrm{IC}_{50}$ ranging from 0.189 to $1.312 \mu \mathrm{M}$ (Table 4). Since both SHIV and SIV can be used for infection of rhesus macaques, ML-OVA will be tested in a non-human primate model for evaluation of its in vivo efficacy against SHIV or SIV infection through vaginal challenge.

A microbicide capable of inhibiting HIV infection by targeting the entry step has the obvious advantage of blocking HIV transmission at the outset of viral infection [51]. By using cell-cell fusion assay, single round viral entry assay, and time-of-addition assay, we demonstrated that ML-OVA, like 3HP- $\beta$-LG, inhibits HIV-1 infection by targeting the early stage of viral replication, particularly the viral entry/fusion processes. Subsequent studies suggested that ML-OVA bound with the cells expressing HIV-1 Env and CD4 (Fig. 6). Using ELISA, we demonstrated that ML-OVA could bind to both gp120 and CD4 molecules, with higher binding efficiency to the former (Fig. 7) and it was effective in blocking the binding of gp120 to sCD4 (Table 5). The binding ability with both gp120 and CD4 may arise from the negatively-charged residues of ML-OVA. Consistently, several negativelycharged polymeric microbicide candidates, such as cellulose acetate phthalate (CAP), carrageenan, cellulose sulfate, PRO-2000, and dextran sulfate, can also interact with gp120 and CD4 to block HIV-1 entry. The positively-charged side chains of lysine and arginine residues of OVA were converted to negatively-charged side chains after modification by anhydride. It is the chemical structure of anhydrates that accounts for the effect of different anhydride OVA modifications on HIV inhibitory activities. Specifically, the only difference between maleic and succinic anhydride was the double bond between $\mathrm{C} 3$ and $\mathrm{C} 4$ in maleic anhydride, which led to the stronger inhibition abilities of ML-OVA over those of SU-OVA on HIV infection. 3-hydroxyphthalic anhydride has a hydrophobic aromatic group, leading to the most potent anti-HIV activity. These findings suggest that the aromatic and unsaturated structure in anhydrides might contribute to the difference in antiviral activities of these modified OVAs.

The disadvantage of protein/peptide drugs, such as T20, is their short half life resulting from the hydrolysis by proteases like trypsin. Since trypsin is the major protease in human and predominantly cleaves peptide chains at the carboxyl side of the amino acids lysine and arginine in human beings, we tested whether ML-modified proteins are sensitive to trypsin. Notably, treatment of MLOVA with trypsin did not affect its anti-HIV-1 activity, indicating that the ML-modified lysine and arginine residues became resistant to trypsin.

An ideal microbicide candidate should be active against HIV-1 infection in the presence of human body fluids, such as seminal fluid or cervicovaginal fluid, because the topical microbicides will be applied intravaginally or intrarectally. In the present study, we tested the effects of seminal fluid and vaginal fluid simulant on anti-HIV activities of ML-OVA. The results indicate that the anti- 

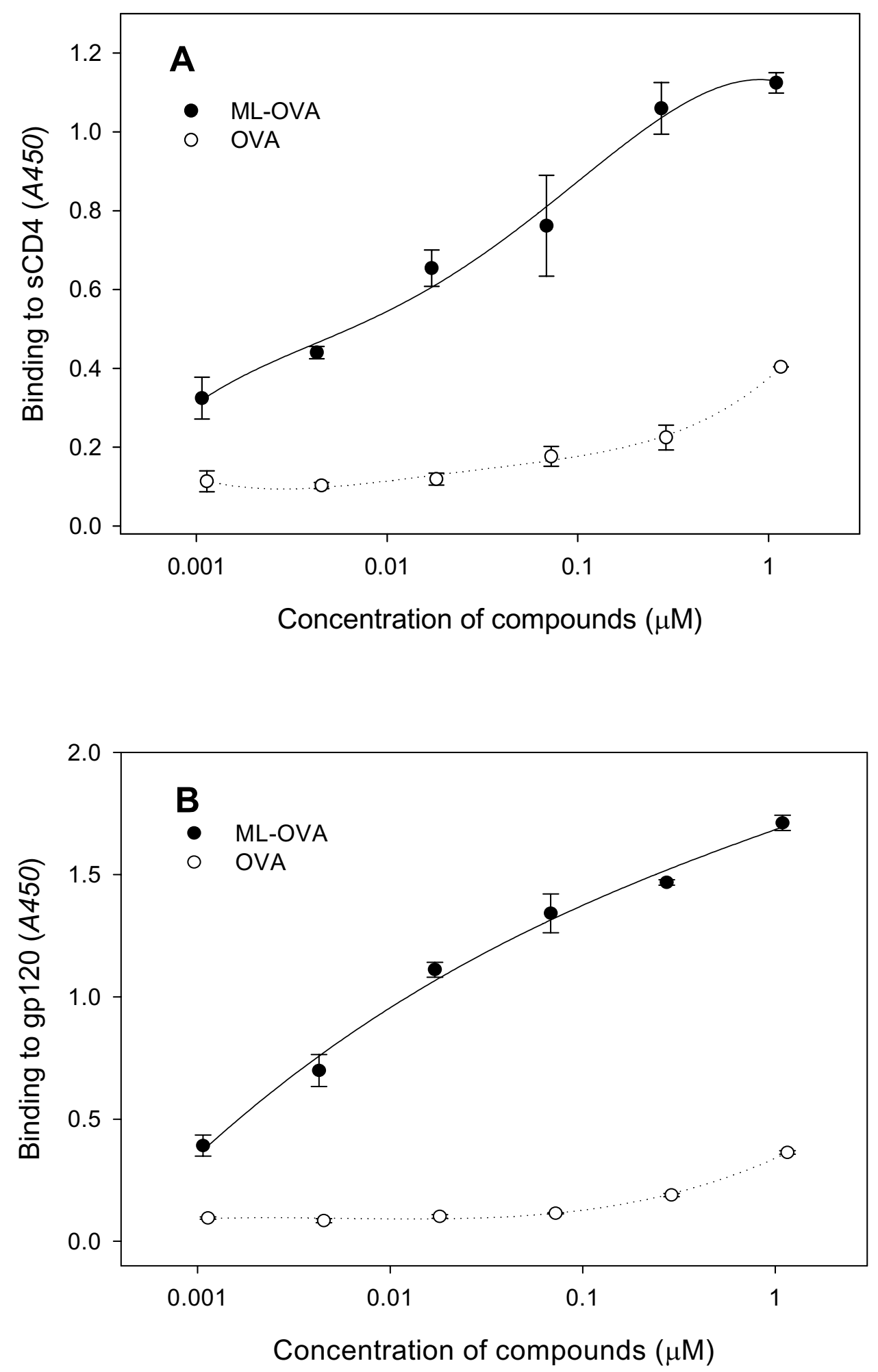

Figure 7 The binding of ML-OVA to SCD4 and gp120 as assessed by ELISA. (A) Dose-dependent binding of ML-OVA to sCD4. (B) Dose-dependent binding of ML-OVA to gp120 from HIV-1 ${ }_{\| \mathrm{IB}}$. Each sample was tested in quadruplicate, the experiment was repeated twice, and the data are presented as means $\pm S D$. 


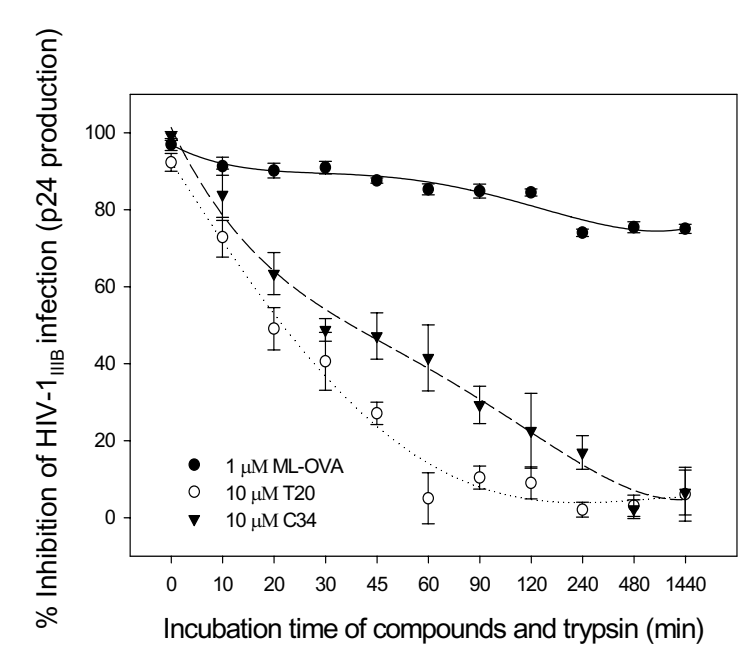

Figure 8 Sensitivity of ML-OVA to digestion by trypsin. The remaining anti-HIV-1 ${ }_{\text {IIB }}$ activity of ML-OVA, T20 and C34 after incubation with trypsin for varying intervals of time was determined by ELISA for p24 antigen production. All the samples were tested in triplicate, the experiment was repeated twice, and data are presented in means \pm SD.

viral activities of ML-OVA are stable in the presence of those fluids (Fig. 9), suggesting that ML-OVA should be active being used as a microbicide.

Currently, there is less enthusiasm for developing polyanionic anti-HIV microbicides due to the failure of clinical trials of several polyanionic polymer-based microbicide candidates, including cellulose sulfate (Ushercell) [52], Carrageenan (Carraguard) [53], and PRO 2000 [54-56], because they have much lower antiviral activity against primary R 5 HIV-1 isolates than laboratory-adapted X4 viruses $[57,58]$. However, we believe that ML-OVA has better potential than those polyanionic polymers for microbicide development because our studies have shown that ML-OVA exhibit highly potent antiviral activity against a broad spectrum of primary R5 HIV-1 isolates (Table 4). Furthermore, ML-OVA can be used in combination with a nonnucleoside reverse transcriptase inhibitor (NNRTI) as a combination microbicide for prevention of infection by HIV-1 strains with resistance to reverse transcriptase inhibitors (RTIs) since our studies have shown that ML-OVA is highly effective against RTI-resistant variants (Table 4). Most recently, Fang, et al. identified a series of poly [styrene-alt-(maleic anhydride)] derivatives with much more potent antiviral activity against both R5 and X4 HIV-1 strains than cellulose sulfate, Carraguard and PRO 2000 [50], which is an example of developing polyanionic polymers with improved anti-HIV-1 efficacy as new microbicide candidates.
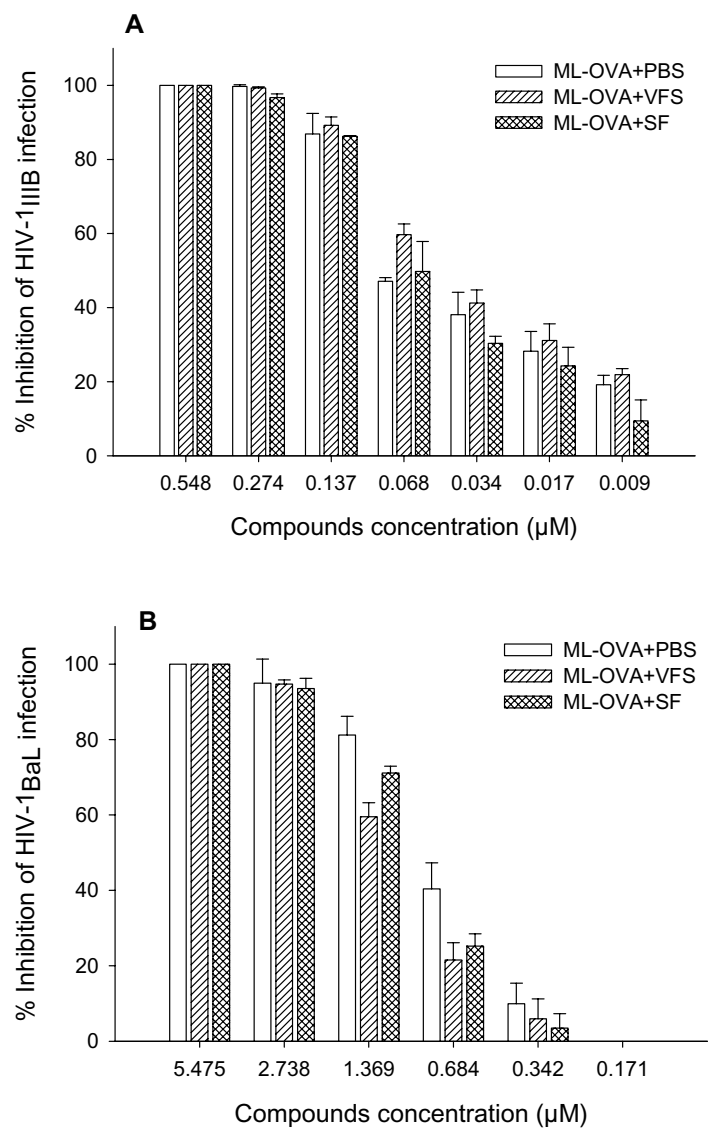

Figure 9 The effect of human SF and VSF on the anti-HIV-1 activity of ML-OVA. The antiviral activities against HIV-1 ${ }_{\text {IIIB }}(\mathrm{A})$ and $\mathrm{HIV}-1_{\text {BaL }}$ (B) in the presence or absence of SF and VSF were assessed using p24 assay as described in the Materials and Methods. The inhibitory activity was detected by an ELISA assay. Each sample was tested in triplicate, and the data are presented as means \pm SD

\section{Conclusion}

In general, the present study provides the optimal conditions ( $40 \mathrm{mM}$ of anhydrides at $\mathrm{pH} 8.5$ ) for large-scale production of anhydride OVAs. By evaluating the anti-HIV activities and analyzing the mechanism of action, we conclude that such modified OVAs are broad-spectrum HIV entry/fusion inhibitors through blocking viral entry. By its broad antiviral potency, resistance to trypsin hydrolysis, easy preparation, low production costs, wide availability and absence of carcinogenic phthalic group, MLOVA has promising potential to be developed as an antiHIV microbicide for preventing HIV sexual transmission.

\section{Competing interests}

The authors declare that they have no competing interests.

\section{Authors' contributions}

$S L$ and SJ conceived the idea and designed research. LL, PQ, JY, LL, ST, HL, XZ and $\mathrm{XC}$ performed research. $\mathrm{LL}, \mathrm{SL}$, and $\mathrm{SJ}$ analyzed the data and wrote the 
paper. SW critically reviewed and edited the paper. All authors read and approved the final manuscript.

\section{Acknowledgements}

We thank Chenglai Xia and Lili He at the Southern Medical University for technical assistance. This work was supported by the National Institutes of Health (U19 Al076964 to SJ), the Natural Science Foundation of China (30729001, U0832001 to SL, 30801412 to LL), the China Ministry of Education's Program (NCET-06-0753 and IRT0731 to SL) and National Key Science and Technology Special Project (2008ZX10001-015 to SL).

\section{Author Details}

1School of Pharmaceutical Sciences, Southern Medical University, 1838 Guangzhou Avenue North, Guangzhou, Guangdong 510515, China and ${ }^{2}$ Lindsley F. Kimball Research Institute, New York Blood Center, 310 East 67th Street, New York, NY 10065, USA

Received: 25 December 2009 Accepted: 26 April 2010

Published: 26 April 2010

\section{References}

1. Balzarini J, Van Damme L: Microbicide drug candidates to prevent HIV infection. The Lancet 2007, 369:787-797.

2. UNAIDS: 2008 Report on the global AIDS epidemic. 2008 [http:// www.unaids.org/en/KnowledgeCentre/HIVData/GlobalReport/2008/ 2008 Global report.asp].

3. Pauwels R, De Clercq E: Development of vaginal microbicides for the prevention of heterosexual transmission of HIV. J Acquir Immune Defic Syndr Hum Retrovirol 1996, 11:211-221.

4. Stone A: Microbicides: a new approach to preventing HIV and other sexually transmitted infections. Nat Rev Drug Discov 2002, 1:977-985.

5. Geuenich S, Goffinet C, Venzke S, Nolkemper S, Baumann I, Plinkert P, Reichling J, Keppler OT: Aqueous extracts from peppermint, sage and lemon balm leaves display potent anti-HIV-1 activity by increasing the virion density. Retrovirology 2008, 5:27.

6. Neurath AR, Debnath AK, Strick N, Li Y-Y, Lin K, Jiang S: Blocking of CD4 cell receptors for the human immunodeficiency virus type 1 (HIV-1) by chemically modified bovine milk proteins: potential for AIDS prophylaxis. J Mol Recogn 1995, 8:304-316.

7. Neurath AR, Jiang S, Strick N, Lin K, Li Y-Y, Debnath AK: Bovine $\beta$ lactoglobulin modified by 3-hydroxyphthalic anhydride blocks the CD4 cell receptors for HIV-1. Nature Med 1996, 2:230-234.

8. Neurath AR, Debnath AK, Strick N, Li Y-Y, Lin K, Jiang S: 3Hydroxyphthaloyl- $\beta$-lactoglobulin: I. Optimization of production and comparison with other compounds considered for chemoprophylaxis of mucosally transmitted HIV. Antiv Chem Chemother 1997, 8:53-61.

9. Neurath AR, Debnath AK, Strick N, Li Y-Y, Lin K, Jiang S: 3Hydroxyphthaloyl- $\beta$-lactoglobulin: II. anti-HIV-1 activity in vitro in environments relevant to prevention of sexual transmission of the virus. Antiv Chem Chemother 1997, 8:141-148.

10. Jiang S, Lin K, Strick N, Li Y-Y, Neurath AR: Chemically modified bovine $\beta$ lactoglobulin blocks uptake of HIV-1 by colon- and cervix-derived epithelial cells. J AIDS Hum Retroviruses 1996, 13:461-462

11. Jiang S, Li Y-Y, Strick N, Neurath AR, George KS, Chuoudhury C, EsmaeliAzad B: Virucidal and antibacterial activities of 3-hydroxyphthaloyl $\beta$ lactoglobulin. In Vaccines 97 Edited by: Chanock RM, Ginsberg HS, Brown F, Lerner RA. New York, Cold Spriong Harbor Laboratory; 1997:327-30.

12. Neurath AR, Strick N, Li YY: 3-Hydroxyphthaloyl beta-lactoglobulin. III. Antiviral activity against herpesviruses. Antivir Chem Chemother 1998, 9:177-184.

13. Kokuba H, Aurelian L, Neurath AR: 3-Hydroxyphthaloyl betalactoglobulin. IV Antiviral activity in the mouse model of genital herpesvirus infection. Antivir Chem Chemother 1998, 9:353-357.

14. Li L, He L, Tan S, Guo X, Lu H, Qi Z, Pan C, An X, Jiang S, Liu S: 3Hydroxyphthalic Anhydride-modified Chicken Ovalbumin Exhibits Potent and Broad Anti-HIV-1 Activity: a Potential Microbicide for Preventing Sexual Transmission of HIV-1. Antimicrob Agents Chemother 2010 in press. doi:10.1128/AAC.01046-09

15. Kluwe WM: Carcinogenic potential of phthalic acid esters and related compounds: structure-activity relationships. Environ Health Perspect 1986, 65:271-278
16. Huber WW, Grasl-Kraupp B, Schulte-Hermann R: Hepatocarcinogenic potential of di(2-ethylhexyl)phthalate in rodents and its implications on human risk. Crit Rev Toxicol 1996, 26:365-481.

17. Jiang S, Lin K, Lu M: A conformation-specific monoclonal antibody reacting with fusion-active gp41 from the HIV-1 envelope glycoprotein. J Virol 1998, 72:10213-10217.

18. Owen DH, Katz DF: A vaginal fluid simulant. Contraception 1999, 59:91-95.

19. Hsu M, Harouse JM, Gettie A, Buckner C, Blanchard J, Cheng-Mayer C: Increased mucosal transmission but not enhanced pathogenicity of the CCR5-tropic, simian AIDS-inducing simian/human immunodeficiency virus SHIV(SF162P3) maps to envelope gp120. Virol 2003, 77:989-998.

20. Fields R: The rapid determination of amino groups with TNBS. Methods Enzymol 1972, 25:464-469.

21. Elton D, Medcalf $L$, Bishop K, Harrison D, Digard P: Identification of amino acid residues of influenza virus nucleoprotein essential for RNA binding. J Virol 1999, 73:7357-7367.

22. Yamasaki RB, Vega A, Feeney RE: Modification of available arginine residues in proteins by p-hydroxyphenylglyoxal. Anal Biochem 1980 109:32-40.

23. Jiang S, Lu H, Liu S, Zhao Q, He Y, Debnath AK: N-substituted pyrrole derivatives as novel human immunodeficiency virus type 1 entry inhibitors that interfere with the gp41 six-helix bundle formation and block virus fusion. Antimicrob Agents Chemother 2004, 48:4349-4359.

24. Jiang S, Debnath AK: Development of HIV entry inhibitors taregeted to the coiled coil regions of gp41. Biochem Biophys Res Commun 2000, 269:641-646.

25. Li M, Li L, Jiang S, Zhang J: A non-infectious assay for detecting HIV-1 Env-induced cell-cell fusion (in Chinese). J Jinan Univ (Med Sci) 2008, 28:576-580

26. Chou TC, Hayball MP: CalcuSyn: Windows software for dose effect analysis. Ferguson, MO 63135, USA, BIOSOFT 1991

27. Chou TC, Talalay P: Quantitative analysis of dose-effect relationships: the combined effects of multiple drugs or enzyme inhibitors. Adv Enzyme Regul 1984, 22:27-55.

28. Jiang S, Lin K, Neurath AR: Enhancement of human immunodeficiency virus type-1 (HIV-1) infection by antisera to peptides from the envelope glycoproteins gp120/gp41. J Exp Med 1991, 174:1557-1563.

29. Pang W, Wang RR, Yang LM, Liu CM, Tien P, Zheng YT: Recombinant protein of heptad-repeat HR212, a stable fusion inhibitor with potent anti-HIV action in vitro. Virology 2008, 377:80-87.

30. Fernandez-Romero JA, Thorn M, Turville SG, Titchen K, Sudol K, Li J, Miller T, Robbiani M, Maguire RA, Buckheit RW Jr, Hartman TL, Phillips DM: Carrageenan/MIV-150 (PC-815), a combination microbicide. Sex Transm Dis 2007, 34:9-14.

31. Fletcher PS, Harman SJ, Boothe AR, Doncel GF, Shattock RJ: Preclinical evaluation of lime juice as a topical microbicide candidate. Retrovirology 2008, 5:3.

32. Neurath AR, Strick N, Li YY, Debnath AK: Cellulose acetate phthalate, a common pharmaceutical excipient, inactivates HIV-1 and blocks the coreceptor binding site on the virus envelope glycoprotein gp120. BMC Infect Dis 2001, 1:17.

33. VanCott TC, Mascola JR, Kaminski RW, Kalyanaraman V, Hallberg PL, Burnett PR, Ulrich JT, Rechtman DJ, Birx DL: Antibodies with specificity to native gp120 and neutralization activity against primary human immunodeficiency virus type 1 isolates elicited by immunization with oligomeric gp160. J Virol 1997, 71:4319-4330.

34. Zhou J, Swiderski P, Li H, Zhang J, Neff CP, Akkina R, Rossi JJ: Selection, characterization and application of new RNA HIV gp 120 aptamers for facile delivery of Dicer substrate siRNAs into HIV infected cells. Nucleic Acids Res 2009, 37:3094-3109.

35. Tomita I, Nakamura Y, Aoki N, Inui N: Mutagenic/carcinogenic potential of DEHP and MEHP. Environ Health Perspect 1982, 45:119-125.

36. Kozumbo WJ, Kroll R, Rubin RJ: Assessment of the mutagenicity of phthalate esters. Environ Health Perspect 1982, 45:103-109.

37. Kluwe WM, Haseman JK, Huff JE: The carcinogenicity of di(2-ethylhexyl) phthalate (DEHP) in perspective. J Toxicol Environ Health 1983 12:159-169.

38. Seo KW, Kim KB, Kim YJ, Choi JY, Lee KT, Choi KS: Comparison of oxidative stress and changes of xenobiotic metabolizing enzymes induced by phthalates in rats. Food Chem Toxicol 2004, 42:107-114 
39. Yu H, Tudor D, Alfsen A, Labrosse B, Clavel F, Bomsel M: Peptide P5 (residues 628-683), comprising the entire membrane proximal region of HIV-1 gp41 and its calcium-binding site, is a potent inhibitor of HIV-1 infection. Retrovirology 2008, 5:93.

40. Neurath AR, Strick N, Li YY: Role of seminal plasma in the anti-HIV-1 activity of candidate microbicides. BMC Infect Dis 2006, 6:150.

41. Huntington JA, Stein PE: Structure and properties of ovalbumin. J Chromatogr B Biomed Sci Appl 2001, 756:189-198.

42. Nisbet AD, Saundry RH, Moir AJ, Fothergill LA, Fothergill JE: The complete amino-acid sequence of hen ovalbumin. Eur J Biochem 1981, 115:335-345.

43. Di TA, Saletti G, Pizza M, Rappuoli R, Dougan G, Abrignani S, Douce G, De Magistris MT: Induction of antigen-specific antibodies in vaginal secretions by using a nontoxic mutant of heat-labile enterotoxin as a mucosal adjuvant. Infect Immun 1996, 64:974-979.

44. Staats HF, Jackson RJ, Marinaro M, Takahashi I, Kiyono H, McGhee JR: Mucosal immunity to infection with implications for vaccine development. Curr Opin Immunol 1994, 6:572-583.

45. Walker Rl: New strategies for using mucosal vaccination to achieve more effective immunization. Vaccine 1994, 12:387-400.

46. Honma K, Kohno Y, Saito K, Shimojo N, Horiuchi T, Hayashi H, Suzuki N, Hosoya T, Tsunoo H, Niimi H: Allergenic epitopes of ovalbumin (OVA) in patients with hen's egg allergy: inhibition of basophil histamine release by haptenic ovalbumin peptide. Clin Exp Immunol 1996, 103:446-453.

47. Mine $Y$, Yang M: Recent advances in the understanding of egg allergens: basic, industrial, and clinical perspectives. J Agric Food Chem 2008, 56:4874-4900

48. National Toxicology Program: NTP Toxicology and Carcinogenesis Studies of Succinic Anhydride (CAS No. 108-30-5) in F344/N Rats and B6C3F1 Mice (Gavage Studies). Natl Toxicol Program Tech Rep Ser 1990, 373:1-173.

49. McCormick DL, Becci PJ, Moon RC: Inhibition of mammary and urinary bladder carcinogenesis by a retinoid and a maleic anhydride-divinyl ether copolymer (MVE-2). Carcinogenesis 1982, 3:1473-1476.

50. Fang W, Cai Y, Chen X, Su R, Chen T, Xia N, Li L, Yang Q, Han J, Han S: Poly(styrene-alt-maleic anhydride) derivatives as potent anti-HIV microbicide candidates. Bioorganic \& Medicinal Chemistry Letters 2009, 19:1903-1907

51. Lederman MM, Jump R, Pilch-Cooper HA, Root M, Sieg SF: Topical application of entry inhibitors as "virustats" to prevent sexual transmission of HIV infection. Retrovirology 2008, 5:116.

52. Van DL, Govinden R, Mirembe FM, Guedou F, Solomon S, Becker ML, Pradeep BS, Krishnan AK, Alary M, Pande B, Ramjee G, Deese J, Crucitti T, Taylor D: Lack of effectiveness of cellulose sulfate gel for the prevention of vaginal HIV transmission. N Engl J Med 2008, 359:463-472.

53. Perotti ME, Pirovano A, Phillips DM: Carrageenan formulation prevents macrophage trafficking from vagina: implications for microbicide development. Biol Reprod 2003, 69:933-939.

54. Joshi S, Dutta S, Bell B, Profy A, Kuruc J, Gai F, Cianciola M, Soto-Torres L, Panchanadikar A, Risbud A, Mehendale S, Reynolds SJ: Phase I safety study of $0.5 \%$ PRO 2000 vaginal Gel among HIV un-infected women in Pune, India. AIDS Res Ther 2006, 3:4

55. Mayer KH, Karim SA, Kelly C, Maslankowski L, Rees H, Profy AT, Day J, Welch $J$, Rosenberg Z: Safety and tolerability of vaginal PRO 2000 gel in sexually active HIV-uninfected and abstinent HIV-infected women. AIDS 2003, 17:321-329.

56. Tabet SR, Callahan MM, Mauck CK, Gai F, Coletti AS, Profy AT, Moench TR, Soto-Torres LE, Poindexter AN III, Frezieres RG, Walsh TL, Kelly CW, Richardson BA, Van Damme L, Celum CL: Safety and acceptability of penile application of 2 candidate topical microbicides: BufferGel and PRO 2000 Gel: 3 randomized trials in healthy low-risk men and HIVpositive men. J Acquir Immune Defic Syndr 2003, 33:476-483.

57. Shattock RJ, Doms RW: AIDS models: microbicides could learn from vaccines. Nat Med 2002, 8:425.

58. Dezzutti CS, James VN, Ramos A, Sullivan ST, Siddig A, Bush TJ, Grohskopf LA, Paxton L, Subbarao S, Hart CE: In vitro comparison of topical microbicides for prevention of human immunodeficiency virus type 1 transmission. Antimicrob Agents Chemother 2004, 48:3834-3844. doi: 10.1186/1742-4690-7-37

Cite this article as: Li et al., Maleic anhydride-modified chicken ovalbumin as an effective and inexpensive anti-HIV microbicide candidate for prevention of HIV sexual transmission Retrovirology 2010, 7:37

\section{Submit your next manuscript to BioMed Central and take full advantage of:}

- Convenient online submission

- Thorough peer review

- No space constraints or color figure charges

- Immediate publication on acceptance

- Inclusion in PubMed, CAS, Scopus and Google Scholar

- Research which is freely available for redistribution
C BioMed Central 